\title{
WHEN A KING SPEAKS OF GOD; WHEN GOD SPEAKS TO A KING: FAITH, POLITICS, TAX EXEMPT STATUS, AND THE CONSTITUTION IN THE CLINTON ADMINISTRATION
}

\author{
RANDY LEE*
}

I

\section{INTRODUCTION}

The Clinton Administration has committed itself to clarifying the role of religion in the public sphere. To that effect, the Administration has released federal guidelines that clarify religious exercise and expression in the federal workplace $^{1}$ and in public schools. ${ }^{2}$ These guidelines have, in fact, reduced confusion and litigation in those intersections of religion and public life. ${ }^{3}$ Administration activities, however, have clouded, rather than clarified, the role religion is to play in another part of the public sphere, political campaigns.

Under the Clinton Administration, the Internal Revenue Service ("IRS") and the Department of Justice ("DOJ") have broken new ground in enforcement of the tax code's ban on "partisan political activity" by tax-exempt religious organizations. 5 . Meanwhile, the President himself has used church buildings $^{6}$ and religious services ${ }^{7}$ for political campaigning, and his speeches

Copyright @ 2000 by Randy Lee

This article is also available at http://www.law.duke.edu/journals/62LCPLee.

* Professor of Law, Widener University, Harrisburg Campus.

I would like to thank Shannon Whitson for technical support and Paula Heider for efforts again both patient and heroic in getting this piece produced. Fredrick Cabell, James Diehm, Mary Kate Kearney, Samuel Levine, H. Jefferson Powell, Loren Prescott, Robert Rodes, Thomas Shaffer, and Peter van Zante provided thoughtful comments to this effort. I would also like to thank my wife and children for encouragement, love, and perspective. Thanks also to many friends including St. Joseph of Coppertino, who knew the wisdom of God, the power of truth, the depth of humility, the necessity of love, and a verse of Luke.

1. Guidelines on Discrimination Because of Religion or National Origin, 41 C.F.R. $\S 60-50.3$ (1998); Guidelines on Discrimination Because of Religion, 29 C.F.R. $§ 1605.2$ (1997). (1999).

2. U.S. Dept. of Educ., Public Schools and Religious Communities: A First Amendment Guide

3. See The President Announces Release of Revised Religious Guidelines for America's Public Schools, May 29, 1998, available in 1998 WL 278240; Religious Freedom Press Paper, Aug. 14, 1997, available in 1997 WL 890103.

4. 26 U.S.C. $\$ 501(c)(3)$ (1994).

5. See Branch Ministries, Inc. v. Rossotti, 40 F. Supp. 2d 15, 22 (D.D.C. 1999).

6. See, e.g., Dan Morrison, Bishop Balks at Clinton Visit: Wary of Political Rally on Church Grounds, NEWSDAY, Oct. 30, 1998, at A43. 
endorsing particular candidates aggressively intertwine the political with the religious. $^{8}$

Critics of the Administration have seen in this inconsistent behavior the spectre of partisanship because the attention of the IRS appears to have been captured only by those religious groups whose political activities were in opposition to the President or his supporters.' ${ }^{9}$ Yet, a closer look suggests that the IRS and the President have moved in different directions because they understand the law differently. While the IRS has sought to give meaning to the code provisions tied to then-Senator Lyndon Johnson's efforts to neutralize political opponents, ${ }^{10}$ the President has acted in accordance with political and religious norms and a constitutional interpretation that has dominated most of American history. ${ }^{11}$

Yet even here, where the Administration's conflicting behavior has created confusion, it has catalyzed efforts to clarify the role of religion in the public sphere. While certainly the Administration cannot claim to have established clear lines for religious involvement in the political realm, as it has in public schools and federal workplaces, it has highlighted a real tension in this area that we have ignored over the years due only to restraint in enforcement and timidity in practice. Now confronted with this tension, we must resolve it.

This tension implicates both the Free Exercise ${ }^{12}$ and Establishment ${ }^{13}$ Clauses of the First Amendment. Does the state prohibit the free exercise of religion when it restricts the questions that religious believers can pose? Does the state prohibit free exercise when it restricts the ability of religious believers to express their answers either to one another or to the outside world? Does the Constitution prohibit the state's establishment of a religion because the document seeks to separate church and state with a wall "high and firm," stead, because it seeks to allow the two to function together in a way that preserves the integrity of both?

In considering the guidance the executive branch has provided to resolve these questions, this article draws upon the positions of both the IRS and the President. ${ }^{15}$ Initially, it concludes that when the state requires churches commit-

7. See C. Fraser Smith, The Political Game: Epilogue on the Election of 1998, BALT. SUN., Nov. 17, 1998, at 2B.

8. See infra text accompanying notes 33-48.

9. See infra note 49 .

10. See Pulpit Politics?, Clev. Plain DeAler, Nov. 9, 1998, at 8B.

11. See id. ("Until 1954, politicking from the pulpit was part and parcel of the electoral process.").

12. U.S. CONST. amend. I ("Congress shall make no law ... prohibiting the free exercise [of religion].").

13. Id. ("Congress shall make no law respecting an establishment of religion.").

14. Branch Ministries, Inc. v. Rossotti, 40 F. Supp. 2d 15, 25 (D.D.C. 1999) (quoting Christian Echoes Nat. Ministry, Inc. v. United States, 470 F. 2d 849, 857 (10th Cir. 1972)).

15. This article does not attempt to resolve conflicts in this area within or between the other branches. See infra text and accompanying notes 76-77. Instead, it builds on the premises developed over the years by Professor H. Jefferson Powell that despite Marbury v. Madison, 5 U.S. (1 Cranch) 137 (1803), constitutional law does not originate solely from the Supreme Court. In fact, Professor Powell concludes that much constitutional law worth studying comes from other branches. See, e.g., H. 
ted to speaking truth in the public square to choose between publicizing their beliefs and remaining tax-exempt, it burdens the free exercise of religion. In this context, for example, the state burdens free exercise when it restricts the questions that churches may place on voter guides or introduce during public debate. This is so because fundamental to the mission to speak truth is the freedom to select the questions that truly matter. ${ }^{16}$ In addition, when the state forecloses churches from attempting to serve as a conscience to power, the state violates the Establishment Clause, because one of the real values of the Establishment Clause is guaranteeing that churches in America retain an unrestricted voice worthy of listening to. These views result both from a common understanding of the nature and pervasiveness of religion, and from America's and other nations' political experiences. From Judah and Israel, across Europe, and into America, the centuries have shown that a state that is denied a moral compass does evil, and a state guided by a moral compass that has lost its integrity within the state's halls of power is worse than a state with no moral compass at all. ${ }^{17}$

If we accept the President's position that religion has a place in public discourse, then we inevitably encounter the following question: After its religious organizations attempt to speak their truths as part of the national debate of conscience, will America embrace, tolerate, or abuse the ensuing discussion?

While at Notre Dame, John Howard Yoder observed the tendency of Catholic people to honor their saints, people like Mother Teresa or Dorothy Day, without following them, ${ }^{18}$ and he further observed that nations are no less capable of engaging in similar self-deception. ${ }^{19}$ Lest there be any doubt, H. Jefferson Powell has advanced that Yoder's observation "certainly applies to American constitutionalism." Similarly this article will argue that the danger in current American political discourse is not that religious language will poison

JeFFERSON POWELl, THE CONSTITUTION AND THE ATTORNEYs GENERAL xvii (1999) [hereinafter POWELL, CONSTITUTION] ("Taken as a whole the opinions of the Attorneys General deserve our attention as important contributions to the task of interpreting and implementing the Constitution."); $\mathrm{H}$. JEFFERSON POWELl, THE MORAL TRADITION OF AMERICAN CONSTITUTIONALISM 88-181 (1993) [hereinafter POWELL, MORAL TRADITION] (discussing the history of constitutional law reflecting leadership in constitutional authority shifting between branches).

16. POWEll, Moral Tradition, supra note 15, at 30 ("What unites participants in a MacIntyraean tradition is as much the problems they think important as the answers they think correct.").

17. See infra text accompanying notes 177-205.

18. See ThOMAs Shaffer, JOHn Howard Yoder: TO A HoOsier LAWYer 32 (forthcoming 2000) (manuscript on file with author). Yoder did not see in this dynamic any hypocrisy or insincerity. Instead, he believed that most people find certain levels of goodness admirable, but either irrelevant or unattainable. See id.

19. See John Howard Yoder, Priestly Kingdom 157-59 (1984). Rich Mullins echoed the notion that sins of the citizen aggregate to become sins of the state. See Rich Mullins, Introduction to "The Just Shall Live," on TwENTY THE COUNTDOWN MAGAZINE REMEMBERS RicH MulLins (1997) (audiotape) ("[D]emocracy isn't necessarily bad politics; it's just bad math. A thousand corrupt minds are just as evil as one corrupt mind.").

20. See Powell, Moral Tradition, supra note 15, at 271. 
the world of politics, but that political participants will gut religious language of all truth. ${ }^{21}$

\section{II}

\section{THE CREATION OF PARADOX}

On Thursday, October 29, 1998, DOJ lawyers appeared in federal district court in Washington, D.C., to defend the IRS's decision to revoke the taxexempt status of the Branch Ministries' church. ${ }^{22}$ Church officials maintained that this was the first time the IRS had ever taken such an action against a church. $^{23}$ The DOJ lawyers argued that the revocation was appropriate because the church had participated in a campaign against a candidate for political office in violation of section 501(c)(3) of the Internal Revenue Code ${ }^{24}$ when it placed a full-page advertisement in both the Washington Times and USA Today four days before the 1992 presidential election. ${ }^{25}$ The advertisement began "Christian Beware. Do not put the economy ahead of the Ten Commandments" and then stated that "Bill Clinton is promoting policies that are in rebellion to God's laws." In support of this latter conclusion, the advertisement referred to Biblical passages and indicated that then-candidate Bill Clinton supported abortion on demand, homosexuality, and the distribution of condoms to teenagers in the public schools. ${ }^{27}$ The main text of the advertisement closed, "How then can we vote for Bill Clinton?" ${ }^{28}$ The following notice was included in fine print at the bottom of the page: "This advertisement was co-sponsored by The Church at Pierce Creek, Daniel J. Little, Senior Pastor, and by churches and concerned Christians nationwide. Tax-deductible donations for this advertisement gladly accepted. Make donations to: The Church at Pierce Creek [address also included]." 29 Branch Ministries characterized the advertisement as merely a

21. See Eerdman's HANDbOOK TO Christianity In AMERICA XXXI (Mark A. Noll et al. eds., 1983) ("The crisis of the church ... is not the crisis of the church in the world, but of the world in the church.” (quoting H. Richard Niebuhr)); see also StANLEY HAUERWAS, AgAinst THE NATIONS: WAR AND SURVIVAL IN A LIBERAL SOCIETY 9 (1992) (acknowledging principle danger in this area is "the temptation of the church ... to accommodate the prevailing culture rather than shape it").

22. See Ira Rifkin, Attorneys Argue "Landmark" Church Political Ads Tax Cases, Religion News SERV., Oct. 30, 1998, available in 1998 WL 7661662.

23. See Branch Ministries, Inc. v. Rossotti, 40 F. Supp. 2d 15, 22 (D.D.C. 1999). Branch Ministries distinguished the only two similar IRS actions as being against a religious radio program and against a "group." Id.

24. See id. at 19.

25. See id. at 17.

26. $I d$.

27. See id.

28. Id.

29. Id. Upon viewing the actual advertisement, one might conclude "fine print" here means barely visible, particularly when the typeface of the funding request is compared to the size of the typeface in the rest of the ad. See id. app.. The advertisement is reproduced in the appendix to this article. See page 437. 
"warning to members of the Body of Christ," not "participation in a political
campaign.",30

Three days after the DOJ argued against the tax-exempt status of Branch Ministries, President Clinton spoke during a worship service at Baltimore's New Psalmist Baptist Church. ${ }^{31}$ The service was carried live on television. ${ }^{32}$ During his address, just two days before the 1998 election, President Clinton introduced several Democratic candidates for office to the assembly of nearly two thousand people. $^{33}$ Each candidate sat in the front pews of the church forming "a "who's who of Democrats up for re-election [that week]_Gov. Parris N. Glendening, Lt. Gov. Kathleen Kennedy Townsend, Sen. Barbara A. Mikulski, two U.S. Congressmen and several state delegates and officials." ${ }^{34}$ President Clinton cited the accomplishments of many of these individuals and explained how he needed Democrats in Congress to help further his agenda. ${ }^{35} \mathrm{He}$ added that "on Tuesday, you're in control of the arithmetic again and you can vote." 36

In his sermon that day, Reverend Walter Thomas of New Psalmist blamed "organized evil" for the dismantling of affirmative action and exhorted the crowd, "Every time you turn around, somebody's at you, somebody's trying to destroy you, somebody's killing your program."37 Building on this theme, President Clinton stressed that the 1998 election was about "whether the people who believe they should divide America can leave you out because you stay home." 38 Drawing on images of Kosovo, Bosnia, the Middle East, Ireland, America's McCarthy era, and tribal warfare in Africa, the President indicated that "turmoil and human misery" were "caused by people who believe that politics is about gaining power over somebody you can look down [on]. It's about dividing the country between us and them." over America today there are people in other churches who have a different view. Who believe that their principles require them to vote only for people at the extreme right wing of the Republican Party." himself as the alternative, one who had "done everything [he] could to bring

30. Id. at 18 .

31. See Smith, supra note 7, at 2B.

32. See id.

33. See David Morgan, Blacks Urged to Vote in Push by Democrats: Clinton and Jackson Strive to Emphasize Importance of Having Minorities Cast Ballots, GLOBE \& MAIL, Nov. 2, 1998, at A12.

34. Larry Witham, Visit to Black Church Creates a Gray Area: IRS Sees No Sin in Move by Democrats, WASH. TiMES, Nov. 3, 1998, at A1. One Republican official, State Delegate Donald Murphy whose district includes the area surrounding the church, also attended the service. Murphy referred to the service as a "political rally." In retrospect, Mr. Murphy indicated that he regretted attending because his presence gave Democrats "cover" to call the event nonpartisan. See Alan C. Miller \& Lisa Getter, Clinton's Appearance Triggers New Church-State Controversy: Baltimore Event Was Billed as a Get-out-the-vote Rally, but it Included Electoral Solicitation, L.A. TIMES, Dec. 29, 1998, at A5.

35. See President William Jefferson Clinton, Remarks to New Psalmist Baptist Church Service 1, 3 , 5 (Nov. 1, 1998) (transcript available in White House Archive Office) [hereinafter Clinton Speech].

36. Id. at 4 .

37. Morgan, supra note 33, at A12.

38. Clinton Speech, supra note 35 , at 5 .

39. Id. at 4 .

40. Id. 
this country together, to reconcile the American people to one another so we could go forward together." ${ }^{41}$

During the speech, President Clinton drew on the Gospel of Matthew and Paul's First Letter to the Corinthians. ${ }^{42}$ In the concluding portion of his speech, the President defined the close relationship he saw between religion and politics:

So I say to you, we believe that our politics should be guided by what our Lord said was the first and most important commandment and the second is like unto it. First we must try to love the Lord, our God, with all our heart. And the second is like unto it, thou shalt love thy neighbor as thyself. ${ }^{43}$

Congressman Elijah E. Cummings, the Democratic Congressman representing the New Psalmist area, arranged the visit because he "hoped to stimulate a heavy turnout for Governor Parris N. Glendenning, who [was] locked in a tight race with Republican Ellen R. Sauerbrey." "To cover the cost of the event, Congressman Cummings solicited $\$ 1,000$ political contributions from supporters who were invited to attend a private reception after the service on church grounds. ${ }^{45}$ At the reception, supporters could meet and be photographed with the President. ${ }^{46}$ The White House knew of this fundraising effort in advance, although New Psalmist officials did not. ${ }^{47}$ Congressman Cummings's office indicated that the effort was necessary because the White House could not cover the cost of the visit because the visit was "political."

Many observers of these two events saw a tension between the actions of the IRS and DOJ and those of the President. ${ }^{49}$ Although the Branch Ministries'

41. Id. at 5 .

42. See id. at 4,5 .

43. Id. at 5 .

44. C. Fraser Smith \& Joanna Daemmrich, Clinton Rallies Democrats to Vote at New Psalmist $<\mathrm{http}: / /$ www.newpsalmist.org/president's_visit.html> (originally published in the BALTIMORE SUN, Nov. 2, 1998).

45. See Miller \& Getter, supra note 34, at A5. Interestingly, the area of the reception, referred to as the "church mansion," is run by a for-profit corporation. See id.

46. See id. Between 100 and 150 people attended the reception, although only 27 contributed to the fund. See id.

47. See id.

48. Id. New Psalmist has included on its Web site a Baltimore Sun news story about the President's visit, which indicates the church also recognized the political nature of the visit. The article is titled "Clinton Rallies Democrats to Vote at New Psalmist," and acknowledges the appearance was arranged to "stimulate a heavy turnout for Gov. Parris N. Glendenning, who [was] locked in a tight race with Republican Ellen R. Sauerbrey." Smith \& Daemmrich, supra note 44.

49. For example, Americans United for Separation of Church and State filed complaints with the IRS over both incidents. See Miller \& Getter, supra note 34, at A5; Joe Nicholson, Church Stripped of Tax Status for Newspaper Advertising, ED. \& PUB., Apr. 10, 1999, at 44; see also Carmen Deardo, The IRS Should Not Be Used as a Tool to Punish Churches, PITT. Post-GAZETTE, May 5, 1999, at A20 ("How is it that the Internal Revenue Service goes after a church for warning Americans about President Clinton's policies but does not take any action against churches which open their pulpits to Bill Clinton and other Democrats for partisan political speeches?"); Edith Pelham, Tax-exempt Churches, Louisville Courier-J., Apr. 13, 1999, at 8A; Pulpit Politics, supra note 10, at 8B ("If there are to be rules, they should be clear. If they are to be enforced, they should be enforced consistently."); Two Sets of Rules, DAILY OKLAHOMAn, Apr. 5, 1999, at 4 ("In Bill Clinton's America, there now seems to be two sets of rules for churches engaged in 'political' activity."). 
Church and New Psalmist Baptist Church both seemed equally willing to intertwine their religious mission with a political election, ultimately the executive branch, in the form of the IRS and DOJ, sought to discourage the former church from doing so, while it aligned itself with the latter's efforts to do so.

Three parallels between the actions of the two churches strike at the heart of this paradox. First, both churches issued a message that a text sacred to their faith favored or disfavored the policies of a particular candidate or party in an upcoming election. Second, both churches indicated to their believers that this relation between policies and sacred text required the believers to act with their vote in a particular manner. Third, both churches sent these messages at the height of the campaign season, only days before the election: Four days for Branch Ministries, only two for New Psalmist. ${ }^{50}$

Viewing these two events within the fuller context of the 1998 election season and its aftermath further emphasizes this tension and the need for its resolution. Two days before his appearance at New Psalmist, for example, President Clinton appeared with New York senatorial candidate Charles Schumer at Saint Sebastian's Church Parish Center in New York City at what Schumer's staff described as a campaign stop. ${ }^{51}$ During that same week, Vice President Albert Gore appeared with Ohio Democratic gubernatorial candidate Lee Fisher and Representative Dennis Kucinich at Mount Sinai Baptist Church in Cleveland and told the gathering that "it's so important that you elect Lee Fisher as your next governor," to which Representative Kucinich added, "Governor Lee Fisher. Say Amen! Lt. Governor Mike Coleman. Say Amen! The Democratic ticket. Say Amen!" ${ }^{2}$ Earlier in the campaign, as the President and his moral fitness for office became campaign issues, voters saw pictures of the President and his family attending church services, ${ }^{53}$ found on their televisions interviews with the President's spiritual advisers, ${ }^{54}$ and found in the President's speeches references to the President's church attendance and religious foundation.

50. Although one might argue that either statement falls short of a direct order to vote in a particular way, the IRS has found political activity in statements even less direct. See, e.g., Tech. Adv. Mem. 89-36-002, Sept. 8, 1989, available in 1989 WL 596078 (finding attempt to "influence voters" in "This November .... Vote ... . Our future depends on it.").

51. See Morrison, supra note 6, at A43.

52. Pulpit Politics, supra note 10 , at $8 \mathrm{~B}$.

53. See, e.g., William F. Buckley, Why Did Starr Emphasize That Tryst Happened Easter Sunday?, SALT LAKE TRIB., Oct. 17, 1998, at A13.

54. See, e.g., Peggy Wehmeyer, 20/20: The President's Pastors: The Men Helping to Repair the President's Soul (ABC television broadcast, Sept. 23, 1998) (interviewing Reverends Tony Campolo and Gordon MacDonald, President Clinton's spiritual advisers); Jim Miklaszewski, NBC Nightly News: Profile: President Clinton Gathers Spiritual Leaders around Him but Some Wonder If It's Spiritual or Political Redemption He's After (NBC television broadcast, Sept. 15, 1998) (including Reverend Tony Campolo). How much of this dialogue was merely a concession to the media is open to discussion. Reverend Phillip Wogaman, a member of the President's spiritual advising team, stressed in a lecture that one's "pastoral zone must be kept personal and private." Patricia Lefevere, Clinton's Pastor Sees Struggle for Nation's Soul, NAT'L. CATH. REP., Feb. 19, 1999, at 7.

55. See, e.g., Bill Plants, CBS Morning News: President Clinton's Videotaped Grand Jury Testimony to be Released to the Public Today (CBS television broadcast, Sept. 21, 1998) (Clinton mentioned in a 
This is not to say that either the Oval Office or the Democratic Party had a monopoly on intertwining church and politics. The Congressional Black Caucus was not opposed to winding its multi-state "get-out-the-vote" bus tour through local churches. ${ }^{56}$ Similarly, Reverend Jesse Jackson acknowledged that his own "get-out-the-vote" initiative was designed to benefit Democratic candidates. ${ }^{57}$ In furtherance of this goal, Reverend Jackson said of Republicans Newt Gingrich and Trent Lott, "You cannot represent Jesus and lobby for Hell.,"58 On the other side of the political spectrum, during the final weekend of the campaign, the Christian Coalition used its own church network and \$3.1 million to distribute forty-five million "voter guides," expected largely to benefit Republicans. ${ }^{59}$

In 1999, confusion, animosity, and suspicion were the fruits of the 1998 election season. In the spring of 1999, the Christian Coalition received a confidential IRS ruling denying the group federal tax-exempt status under Section 501(c)(3). ${ }^{60}$ The denial further heated a pre-existing legal battle between the IRS and the Landmark Legal Foundation over a Freedom of Information Act request for "the names of anyone who had requested audits or investigations of 501(c)(3) tax-exempt organizations." nounced that it would restructure itself and continue its efforts in the public

speech to the Congressional Black Caucus that he had "to go pick up the first lady and try to avoid being late for church."); Dan Rather, Special Report/Newscast: House of Representatives Votes Overwhelmingly to Release Ken Starr's Complete Report on President Clinton; President Apologizes Again for his Extra Marital Affair (CBS television broadcast Sept. 11, 1998) (President Clinton explaining to the nation that "to be forgiven, more than sorrow is required, at least two more things. First, genuine repentance, a determination to change and to repair breaches of my own making. I have repented.").

56. Chuck Raasch, Lines Between Church, State Blur in Elections; Does Lewinsky Matter?, GANNETT NEWS SERV., Oct. 29, 1998, available in 1998 WL 5637617.

57. Morgan, supra note 33, at A12 (Reverend Jackson noting, "when we did vote in 1986, Democrats regained the Senate. When we didn't in 1994, Newt took over the House.”). Reverend Jackson's political activities over the years suggest a particularly challenging question in this area: Can one separate the political activities of a particular religious figure from any ministry or church with which he may be associated? For a discussion of the religious aspects of Reverend Jackson's 1988 presidential campaign, see Erik J. Ablin, The Price of Not Rendering to Caesar: Restrictions on Church Participation in Political Campaigns, 13 Notre Dame J. L. EThiCs \& Pub. POL'Y 541, 559-61 (1999). For a related topic, see McDaniel v. Paty, 435 U.S. 618 (1978) (holding that states cannot ban clergy from legislative service).

58. Fredrick Kunkle, Jackson Pushes for Turnout to Survive the GOP Deluge, NeWARK STARLEDGER, Oct. 19, 1998, at 016 (quoting Reverend Jackson).

59. Morgan, supra note 33, at A12.

60. See Mary Jacoby, Christian Coalition is denied tax-exempt status, ST. Petersburg Times, June 10, 1999, at 1A. For a more complete discussion of the background of this case, see Ablin, supra note 57 , at 554-58.

61. IRS Rules: Question: Does the IRS have to abide by the same laws that apply to all other government agencies? Answer: It all depends on Judge Henry Kennedy., WALL ST. J., June 4, 1999, at A16. As of March 1997, the IRS was investigating roughly 50 tax-exempt organizations for "improper political activity." Conservatives were complaining that Administration critics were being targeted. See Elizabeth MacDonald, Group Targets Politically Active Churches for Audits, WALL ST. J., Mar. 20, 1997, at A18. The matter shows few signs of going away. See Where's Janet, WALL ST. J., Nov. 19, 1999, at A20 ("This week, for example, the AP boldly stated that 'officials in the Democratic White House and members of both parties in Congress have prompted hundreds of audits of political opponents in the 1990s."'). 
sphere. $^{62}$ Perhaps encouraged by the IRS action against Branch Ministries, Americans United for Separation of Church and State ("AUSCS") threatened to file a section 501(c)(3) complaint with the IRS if the Catholic Archdiocese of Philadelphia published a voter's guide for the city's 1999 primary election. ${ }^{63}$ The group also warned other churches across the county that "they could forfeit their tax-exempt status by working too closely with partisan political groups, particularly the Christian Coalition." ${ }^{64}$ Unshaken, the Archdiocese published the guide. ${ }^{65}$ In response, six conservative U.S. Senators requested that DOJ investigate whether AUSCS had "attempted to disenfranchise religious voters by intimidating people of faith into not participating in the political process." ${ }^{\circ 6}$

Based on the arguments raised by DOJ in Branch Ministries v. Rossotti, one might expect that the executive branch would attempt to resolve the apparent paradox in its behavior by explaining that the Branch Ministries incident was particularly offensive to Section 501(c)(3) for two reasons. First, although both the Branch Ministries and New Psalmist incidents were coupled with fundraising efforts, the fundraising efforts of Branch Ministries solicited tax-deductible donations for the political advertisement, ${ }^{67}$ while the funds raised to support the New Psalmist effort were raised apart from the church and were political, non tax-deductible contributions. In effect, DOJ would maintain that section 501(c)(3) would not have been offended had Branch Ministries not solicited funds in the ads, or alternatively had Branch Ministries sent all its members door-to-door across the country expressing this same message. This argument, however, misses the concern of Section 501(c)(3), which requires that the religious entity "not participate in, or intervene in (including the publishing or distributing of statements) any political campaign on behalf of (or in opposition to) any candidate for public office," ${ }^{, 68}$ regardless of how the religious entity

62. See Mark Sherman, Christian Coalition Ends Nonprofit Bid, Plans Big Shake-up, ATLANTA J. \& ConsT., June 11, 1999, at 3A.

63. See Group threatens to report Philadelphia diocese to IRS, NAT'L CATH. REP., Apr. 16, 1999, at 8 [hereinafter Diocese].

64. Brownback wants group, TOPEKA CAP. J., July 23, 1999 [hereinafter Brownback], available in 1999 WL 20056337.

65. See Diocese, supra note 63, at 8 . In the subsequent general election, both Democratic and Republican mayoral candidates made church visits the Sunday before the election. In fact ultimate victor Democrat John Street spoke at two churches that day and provided campaign literature and pew fans with his picture to parishioners inside the churches. Such campaigning is not novel in Philadelphia politics. Philadelphia's first African-American mayor, Wilson Goode, a Baptist deacon, described churches that provided core volunteers and donors as "the energy and spirit" of his 1983 campaign. See Tom Infield \& Maria Panaritis, Katz and Street Seek to Gain the Faith of Churchgoers, PHILA. INQUIRER, Nov. 1,1999, at A1, A6.

66. Brownback, supra note 64 , at 1 .

67. Brief for Defendant at 21, Branch Ministries, Inc. v. Rossotti, 40 F. Supp. 2d 15 (D. D. C. 1999) (No. 1:95CV00724-PLF) [hereinafter Defendant's Brief]; see also Branch Ministries, Inc. v. Rossotti, 40 F. Supp. 2d 15, 21 (D.D.C. 1999).

68. 26 U.S.C. $\$ 501(\mathrm{c})(3)$ (1994). This prohibitory language appears in both $\S 501(\mathrm{c})(3)$, which deals with the tax-exempt status of an organization, and in 26 U.S.C. $\$ 170$ (c)(1994), which deals with organizations that may receive tax-deductible contributions. The parallel language may explain the relationship DOJ sees between charitable-contribution status and tax-exempt status, although organizations enjoying one status do not always enjoy the other. See Henry Hansmann, The Rationale for Ex- 
funds the activity. Thus, differences in funding strategies do not change the fact that both churches participated in political campaigns on behalf of, or in opposition to, a candidate for public office. ${ }^{69}$

Furthermore, this factual distinction may not even exist for three reasons. First, although Congressman Cummings offset the President's travel costs with political contributions, New Psalmist still turned over its building, pulpit, and service, all regularly supported with tax-deductible contributions, to the President's political message. Second, the telecast of the New Psalmist service might have been paid for with church funds from the church's television outreach ministry. ${ }^{70}$ In that scenario, the public dissemination of both the Branch Ministries and the New Psalmist political messages would have been financed solely with tax-deductible contributions. One might also consider whether the New Psalmist broadcasts concluded with an invitation for financial support. If so, the New Psalmist and Branch Ministries situations would appear to be identical with respect to funding. Finally, through the end of 1999, New Psalmist profited from the sale on its Web site of video cassettes of the President's speech and the service's homily. ${ }^{71}$ Thus, "political funds" generated by the President's speech also enjoyed a privileged status.

As its second reason, the executive branch could argue that the Branch Ministries incident was more troublesome because of the nature of that church's political participation: While New Psalmist merely turned its pulpit over to a political message to be delivered inside the church, Branch Ministries sent its message outside the church through the newspapers. ${ }^{72}$ Ultimately, however, this distinction is illusory. The broadcast of the New Psalmist service over live television carried the service's political message far beyond the confines of the New Psalmist Church.

Although not helpful in explaining the paradox between Branch Ministries and New Psalmist, this second distinction, argued by DOJ in Branch Ministries, ${ }^{73}$ does bring us to the heart of the issue those two events present: What

empting Nonprofit Organizations from Corporate Income Taxation, 91 YALE L.J. 54, 72 (1981). For a discussion of problems peculiar to the tax-exempt status of religious organizations that would not be experienced in allowing deductions for charitable contributions, see Boris I. Bittker \& George K. Rohdert, The Exemption of Nonprofit Organizations from Federal Income Taxation, 85 YALE L.J. 299, 342-45 (1976).

69. The revocation of tax-exempt status issued by the IRS in this case indicated that "contributions covered most of the cost $[\$ 44,500]$ of the ads." It is not clear, however, that these contributions were made in response to the ads themselves. Interview with Mark Trupic, Attorney for Branch Ministries, in Wash., D.C. (Aug. 19, 1999). Meanwhile, Congressman Cummings's efforts to raise non-taxdeductible campaign funds to offset the President's travel expenses netted funds of roughly $\$ 27,000$. See Miller \& Getter, supra note 34, at A5.

70. New Psalmist has an extensive radio and television broadcast schedule throughout the week. See Radio \& TV Broadcast Schedule (visited Apr. 19, 2000) <http://www.newpsalmist.org/radio\&tv. html $>$.

71. See New Psalmist Baptist Church Sermon Listing (visited Oct. 20, 1999) <http://www. newpsalmist.org/audio_video.html $>$. 21.

72. See Defendant's Brief, supra note 67, at 21; see also Branch Ministries, Inc., 40 F. Supp. 2d at

73. See Defendant's Brief, supra note 67, at 21. 
level of church involvement in politics must the state permit in deference to both the Establishment and Free Exercise Clauses. ${ }^{74}$ In the end, it becomes clear that we struggle here not so much with a question of tax-exempt status as with a question of what role churches may play in public debate on political discourse. At the heart of Branch Ministries was the church's constitutional defense that the action of the IRS "substantially burdened [the church's] right to freely exercise its religion."

In Branch Ministries, the court considered ${ }^{76}$ the case within the doctrine that the Supreme Court enunciated in Sherbert v. Verner: Absent a compelling interest, the government may not force an individual to "choose between following the precepts of her religion and forfeiting benefits, on the one hand, and abandoning one of the precepts of her religion." 77 The Justice Department argued successfully that although the IRS had in fact required the church to make a choice, that choice did not require the church to abandon a precept of its faith; rather, the IRS had merely required the church to choose between focusing its energy exclusively on its religious activities and, thereby, retaining its taxexempt status, or dividing its energy between religious and political activities at the expense of that status. ${ }^{78}$ As the court perceived the issue, "( $(t)$ hat choice is unconnected to plaintiffs' ability to freely exercise their religion. Plaintiffs therefore have not demonstrated that the IRS substantially burdened their free exercise of religion." 79

For this argument to prevail, however, one must assume that engagement in what the state carves out as partisan political activity cannot be an element of one's religion. ${ }^{80}$ The validity of this assumption depends, of course, on how "partisan political activity" and "religion" are defined.

74. See U.S. Const. amend I.

75. See 40 F. Supp. $2 d$ at 24.

76. See id at 25 .

77. 374 U.S. 398, 404 (1963). Two developments made consideration of Sherbert viable here. First, in Branch Ministries, the church asserted rights both under the Constitution and the Religious Freedom Restoration Act, 42 U.S.C. § 2000bb (1993) ("RFRA"). While the Supreme Court had declared RFRA unconstitutional with respect to state and local governments in Boerne v. Flores, 521 U.S. 507 (1997), in Branch Ministries, DOJ did not challenge RFRA's application to the federal government. See Branch Ministries, 40 F.Supp. $2 d$ at 24 n.6. In addition, consistent with EEOC v. Catholic University of America, 83 F.3d 455, 467 (D.C. Cir. 1996), the Branch Ministries court held open the possibility that Employment Division Department of Human Resources of Oregon v. Smith, 494 U.S. 872 (1990), did not foreclose all free exercise challenges to neutral laws. See Branch Ministries, 40 F. Supp. 2d at 24. This article does not seek to resolve the ultimate fate of either RFRA or Smith. Rather, it focuses primarily on the interpretations of law the executive branch is making in this area. For a pragmatic discussion of the status of Smith, see Jason M. Sneed, Regaining Their Political Voices: The Religious Freedom Restoration Act's Promise of Delivering Churches from the Section 501(c)(3) Restrictions on Lobbying and Campaigning, 13 J.L. \& POL. 493, 502-03 (1997).

78. See Defendant's Brief, supra note 67, at 14 ("BMI, however, can elect today to operate as a $\S 501(c)(3)$ entity, or it can be a tax-exempt social welfare organization under $\S 501$ (c)(4) or a political action committee under $§ 527 . ”)$.

79. 40 F. Supp. $2 d$ at 25.

80. In Bob Jones University v. United States, 461 U.S. 574, 603-04 (1983), the Supreme Court distinguished between a state action placing a substantial impact on the operations of a religious organization and a state action placing such an impact on the organization's ability to observe their religious tenets. 
Treasury regulations provide some insight into what the IRS considers partisan political activity. Included within the definition of that term is the phrase "the publication or distribution of written statements or the making of oral statements on behalf of or in opposition to" a candidate for public office. ${ }^{81}$ To determine whether such a statement has been made, the IRS considers a number of factors, including the size of the targeted audience and whether there was intent to target the statement to a particular area in which an election will take place or to time the statement to coincide with an election. ${ }^{82}$ The IRS has also established four guidelines to address the substance of the statements:

(1) the degree to which the expressed "viewpoints or positions [are] unsupported by facts";

(2) the degree to which the "facts that purport to support the viewpoints or positions are distorted";

(3) the degree to which the statement makes "substantial use of inflammatory and disparaging terms and expresses conclusions more on the basis of strong emotional feelings than of objective evaluations"; and

(4) the degree to which the approach used in the statement "is not aimed at developing an understanding on the part of the intended audience or readership because it does not consider their background or training in the subject matter." 83

Determinations based on these considerations depend "upon all the facts and circumstances of each case. $"$ " No single factor is necessarily determinative. For example, while in some settings the timing of a statement outside an election season will weigh heavily in making the statement nonpolitical, ${ }^{85}$ in other contexts, a similar timing will not. ${ }^{86}$ Furthermore, a token approach in the statement to providing recipients with a balanced view will not always ensure that the statement is not labeled political. ${ }^{87}$ Ultimately, the standard in determining whether a particular statement is political appears to be whether " $\mathrm{a}$ reading of these materials by the average person ('the man in the street') could only result in he/she [sic] reaching the conclusion" that the statement had been made on behalf of or in opposition to a particular candidate. ${ }^{88}$

81. Treas. Reg. § 1.501(c)(3)-1(c)(3)(iii) (1990). But see id. § 1.501(c)(3)-1(d)(2) (1990):

The fact that an organization, in carrying out its primary purpose, advocates social or civic changes or presents opinion on controversial issues with the intention of molding public opinion or creating public sentiment to acceptance of its views does not preclude such organization from qualifying under Section 501(c)(3) so long as it is not an "action" organization.

82. See Tech. Adv. Mem. 89-36-002 (Sept. 8, 1989), available in 1989 WL 596078. Technical advice memoranda, such as this one, are documents issued by the IRS National Office for the benefit of field agents but are not considered binding authority.

83. Rev. Proc. 86-43, 1986-2 C.B. 729 (distinguishing educational activity from political activity).

84. Rev. Rul. 78-248, 1978-1 C.B. 154. Revenue rulings are issued by the IRS as advisory opinions and, unlike technical advice memoranda, may serve as binding authority.

85. See Tech. Adv. Mem. 89-36-002 (Sept. 8, 1989), available in 1989 WL 596078.

86. See Tech. Adv. Mem. 91-117-001 (Apr. 26, 1991), available in 1991 WL 778438.

87. See id. Token distribution of materials supportive of Democrats did not alter that a course widely supportive of Republicans was political.

88. Id.; see also Tech. Adv. Mem. 89-36-002 (Sept. 8, 1989) (advising no violation because it was "arguable that the ads could be viewed as nonpartisan"), available in 1989 WL 596078. 
In the particular context of voting records or candidates' issue statements, such as those produced by the Christian Coalition that brought a response from the IRS, ${ }^{89}$ the IRS has applied these considerations to generate certain guidelines for what it will not view as partisan political activity. Within those guidelines, churches may make records or issue statements available to the general public without being political, so long as the documents or statements cover a "wide range of subjects," "contain no editorial opinion," and their "contents and structure do not imply approval or disapproval" of any candidates or their voting records. ${ }^{90}$ Further, the wording of questions in the documents may not evidence a bias on certain issues, ${ }^{91}$ nor may the selection of issues to be included place an "emphasis on one area of concern."

Within this standard, the statements at the New Psalmist Baptist Church ${ }^{93}$ appear as partisanly political, or more so, than those made by Branch Ministries. ${ }^{94}$ Both statements were disseminated to a broad audience at the height of the election season. Although both statements attempted to support their positions with "facts" by tying the evils of their opponents or their own goodness to their sacred text, ${ }^{95}$ each, viewed in light of the IRS guidelines, still could be considered to be inappropriately seeking to inflame and draw on strong emotional feelings rather than objective evaluations. To do this, Branch Ministries focused on a narrow band of issues, such as abortion, condom distribution in schools, and homosexuality, which were particularly sensitive to its audience. ${ }^{96}$ Through the speeches of Reverend Thomas and President Clinton, New Psalmist similarly targeted sensitive issues ${ }^{97}$ and added to that inflammatory phrases like "trying to destroy you," "killing your program," "extreme right wing," and "gaining power" exclusively to "look down" on other people. ${ }^{98}$ Furthermore, both statements ultimately would leave the average person with the impression that they disfavored a particular candidate: the Branch Ministries statement through its rhetorical question of "warning," "How then can we vote for Bill Clinton?" "; the New Psalmist statement by its call to defeat Republicans who seek to "divide America." 100 One could even add to the case for a political nature to the New Psalmist statement that it not only called for opposition to certain candidates but also called for the support of alternative candidates, ${ }^{101}$ a step the Branch Ministries statement did not take.

\footnotetext{
89. See supra text accompanying notes 59-62.

90. Rev. Rul. 78-248, 1978-1 C.B. 154.

91. See id.

92. Id.

93. See supra text accompanying notes 33-48.

94. See supra text accompanying notes 26-30.

95. See supra text accompanying notes 27-28, 42-43.

96. See supra text accompanying notes 27 .

97. See supra text accompanying note 35-37.

98. See supra text accompanying notes $37-40$.

99. See supra text accompanying note 28,30 .

100. See supra text accompanying notes 39-40.

101. See supra text accompanying notes $34-35$.
} 
If both statements are partisan political activities, then the holding of Branch Ministries ${ }^{102}$ can be squared with the President's New Psalmist statement only if the New Psalmist statement was religious while the Branch Ministries statement was not. To this end, DOJ would have to argue, as noted earlier, that only the New Psalmist statement was religious because it was delivered from the church pulpit while the Branch Ministries statement appeared in the newspaper. We may consider that argument only if we permit ourselves to ignore that the New Psalmist statement appeared on television. Assuming such permission, the next part of the article will consider whether the concept of religion can be contained in a definition that confines it to expressions within the church walls.

III

\section{THE Right OF FREE EXERCISE OF A RELIGION THAT CUTS TO OUR SOULS}

To respond to DOJ's position that religious messages are only those messages delivered within a religious building and service, one must remember that this position's foundation rests on the assumption that partisan political activity and religious activity exist in mutually exclusive spheres. As such, in this culture of separation, the church is allowed to cross over into the political sphere from the pulpit, not because it has any business commenting on issues politic, but because the cure for such a crossing is worse than the disease. Policing would require monitoring sermons, a proposition that conjures images of government moles serving as church spies and state officials with notepads scribbling down Sunday quotes from the front pews, ${ }^{103}$ effectively creating the most extreme form of day-to-day evaluation of religion, an evaluation that the Supreme Court has held the Constitution seeks to avoid. ${ }^{104}$

DOJ does not err in believing that monitoring the pulpits of all the houses of worship in America would be unseemly and unwieldy. It is mistaken, however, in its fundamental assumption that religion can be kept within a sphere that does not spill over into politics or that religion can be contained within the walls of a church building. Such an assumption ignores both the nature and path of the concept of religion that originally demanded protection in the First Amendment, ${ }^{105}$ a concept that President Clinton has captured in his conversations with the American people.

102. Branch Ministries v. Rossotti, 40 F. Supp. 2d 15, 25 (D.D.C. 1999).

103. The film Gospa (Penland Production Co. 1994) (on file with Dupage Marian Center, Westmont, Illinois), which deals with Communist persecution of the Catholic Church in the former Yugoslavia, captures this image in a particularly haunting scene. For a less politically focused view of events underlying that film, see the documentary Beyond The Fields (Michelangelo Films 1995) (on file with DuPage Marian Center, Westmont, Illinois).

104. See Walz v. Tax Comm'n of N.Y., 397 U.S. 664, 674-75 (1970) (allowing New York City to exempt churches from property taxes).

105. U.S. Const. amend. I ("Congress shall make no law ... prohibiting the free exercise of religion."). 
As the President has described America's religious beliefs, "they represent the essence of our personal values," and they manifest themselves in our behavior in ways that allow us to "live up to [our] full potential."108 Not only has the President captured the depth and empowering nature of religion, but he has also captured its pervasiveness in people's lives. For example, in explaining the need for his guidelines for religion in the public sphere, President Clinton has pointed out that people of faith are not expected to "leave their religion at the schoolhouse door," federal workplace door. ${ }^{110}$ It follows that just as the state cannot expect to be able to lock religion out of schools and offices, it cannot expect to be able to lock religion inside churches. As President Clinton pointed out at New Psalmist, there are those, like himself, who "believe that our politics should be guided by what our Lord said."

While President Clinton is a Protestant, ${ }^{112}$ his religious conclusions resonate with various traditions. The Jewish people, for example, have been instructed to "love the Lord, your God, with all your heart, and with all your soul, and with all your strength," merely those that are apolitical, so that He may "make straight your paths."114 Their prophets counseled not only the kings of Israel and Judah on matters of

106. Proclamation No. 7063, 63 Fed. Reg. 3243 (1998) (Religious Freedom Day, 1998) [hereinafter Religious Freedom Day].

107. Radio Address of the President to the Nation (May 30, 1998), available in 1998 WL 278250.

108. Id. President Clinton provided a concrete example of this at a prayer breakfast for religious leaders, noting that among "the three major determinants in whether young people use drugs or not was ... whether they had a connection to a church." President Bill Clinton, Remarks at a Breakfast with Religious Leaders 3 (Sept. 11, 1995), available in 1995 WL 15155577 [hereinafter Prayer Breakfast].

109. Religious Freedom Day, supra note 106. President Clinton has emphasized that not only is interaction by church and state inevitable in the school, it is also desirable. He explains that schools

help to nurture [students'] souls by reinforcing the values they learn at home and in their communities. I believe one of the best ways we can help our schools to do this is by supporting students' right to voluntarily practice their religious beliefs, including prayer in school, and to pursue religious activities on school grounds.

Radio Address of the President to the Nation (radio broadcast, May 30, 1998), available in 1998 WL 278250.

110. Id. (noting that guidelines "to reinforce the right of religious expression in the federal workplace... ensure that federal employees may engage in personal religious expression to the greatest extent possible").

111. Clinton Speech, supra note 35, at 5 .

112. President Clinton was raised as and remains a Baptist. See Miklaszewski, supra note 54. He is also familiar with other Christian traditions: The President frequently attends a Methodist Church in Washington, see Lefevere, supra note 54, at 7, and attended Georgetown, a Catholic college, see Prayer Breakfast, supra note 108, at 2.

113. Deuteronomy 6:5.

114. Proverbs 3:6; see also Samuel Levine, The Broad Life of the Jewish Lawyer: Integrating Spirituality, Scholarship and Profession, 27 TEX. TECH L. REV. 1199, 1204 (1996) ("[A] religious individual who engages in a secular career has the opportunity to live a 'broad life,' one in which religious values are central not only to the overtly spiritual activities in life, but also to the more mundane activities that are part of a secular career."). Professor Levine is a rabbi and a former assistant district attorney and judicial clerk. 
state $^{115}$ and of war, ${ }^{116}$ but they were called to counsel foreign kings as well. ${ }^{117}$ In the Catholic tradition, when the apostle Peter, considered to be that church's first pope, found himself caught between God and the laws of men, he responded that it was impossible for him to refrain from acting for God's glory. ${ }^{118}$ Nearly 2,000 years later, the French Foreign Minister Delcaseé observed that the acts of subsequent popes are necessarily political given the realm of a pope's influence. He noted that any pope who acted in ignorance of this fact acts "very dangerously both for the church and the world."119 Perhaps the most powerful statements regarding the reach of faith can be found in the Muslim tradition, which teaches that "a study of the world is a study of the miracles (creations) of God and God's unicity" and that "the whole world is nothing but a cosmic manifestation of the divine."120

Believing faith to have this depth and breadth is not limited to Abrahamic traditions. ${ }^{121}$ For example, similar support for the President's conclusions could be drawn from the Buddhist or Hindu traditions. ${ }^{122}$ In fact, with a few notable exceptions, ${ }^{123}$ it is not the faith tradition that determines the validity of the

115. See, e.g., 2 Chronicles 16:7-9 (Hanani advises King Asa on alliances).

116. See, e.g., id. 18:5-27 (the kings of Israel and Judah consult the prophets on whether to attack Ramoth-Gilead).

117. See, e.g., Genesis 41 (Joseph interprets the dreams of Pharaoh and serves as his adviser on domestic policy); Esther 10:3 (King Ahasuerus raises Mordecai to his second in command); Daniel 2:47-48 (King Nebuchadnezzar of Babylon makes Daniel a chief advisor because God's wisdom present in Daniel); Jonah 3 (the king of Ninevah responds to the prophet Jonah).

118. Acts 4:19:20 ("Whether it is right in the sight of God for us to obey you rather than God, you be the judges. It is impossible for us not to speak about what we have seen and heard.").

119. Anthony Rhodes, The VATiCAN IN the Age of the Dictators 1922-1945, at 14 (1973). Accord Bill Tammeus, No Such Thing as "Exclusively Religious," KAN. CITY STAR, Aug. 22, 1999, at L3 (identifying the Pope as "politically potent" and disputing that the Pope "can conceive of a way to separate religion from other aspects of life"). A statement of the U.S. Catholic Conference also attests to the commonality of spiritual and political witness. The statement pointed out that

[i]n the Catholic Tradition, citizenship is a virtue; participation in the political process is an obligation. We are not a sect fleeing the world, but a community of faith called to renew the earth. The 1996 elections provide new opportunities to replace the politics of polarization and false choices with the politics of participation and the common good.

Administrative BoARd OF THE United STATES CATHOLIC CONFERENCE, Political Responsibility: Proclaiming the Gospel of Life, Protecting the LEAst AmONG Us, AND PURSUING THE COMMON GOOD 7 (1995).

120. Azizah Y. al-Hibri, Faith and the Attorney-Client Relationship: A Muslim Perspective, 66 FORDHAM L. REV. 1131, 1134 (1998).

121. See Timothy W. Floyd, The Practice of Law as Vocation or Calling, 66 FordHAM L. REV. 1405, 1411 (1998); Randy Lee, The Immutability of Faith and the Necessity of Action, 66 FORDHAM L. REV. $1455,1459-64$ (1998).

122. See, e.g., Kinji Kanazawa, Being a Buddhist and a Lawyer, 66 FordHAM L. REV. 1171 (1998); K.L. Seshagiri Rao, Practitioners of Hindu Law: Ancient and Modern, 66 FORDHAM L. REV. 1185 (1998).

123. See David M. Smolin, A House Divided? Anabaptist and Lutheran Perspectives on the Sword, 47 J. Legal Educ. 28, 29-32 (1997). See generally COMPUlsory EduCATION AND the Amish: THE RIGHT NOT TO BE MODERN (Albert N. Keim ed., 1975) (hereinafter THE AMISH); see also Stephen Arons, Compulsory Education: The Plain People Resist, in THE AMISH, supra, at 124; John A. Hostetler, The Cultural Context of the Wisconsin Case, in THE AMISH, supra, at 99, 102-03. But see Robert F. Cochran, Jr., Introduction to Christian Perspectives on Law and Legal Scholarship, $47 \mathrm{~J}$. LEGAL EDUC. 1, 8-9 (1997) (pointing out that "Separatist" Christian cultures can be seen as seeking to 
President's conclusions; rather, it is the vitality with which a particular member of a tradition embraces her faith that determines how accurate those conclusions will appear in any given context. As the Reverend Peggy Cantwell has described it,

[i]f the religion is simply a set of rituals or motions a person repeats at set times of the week or the year, or a system designed to make one a better person or elevate one to higher status, religion will make little difference. The personal interaction with the living God which cuts into our souls and our lives, "religion" which activates our decision-making process and gives us a frame of reference for conduct, behavior and lifestyle-that religion will have great relevance to the lawyer's work. ${ }^{124}$

Not only does the President's view of religion and politics transcend the divides of religious traditions, but it stands as internally consistent: Beliefs held as deeply and pervasively as religious beliefs must intersect with the realm of politics. In this light, Professor Robert M. Calhoon has pointed out that the very image created by the term "separation of church and state" is flawed because from the outset in America, "[c]hurch and state have not so much confronted each other as each has arisen from, and has sought relationship with, the whole society." As Calhoon explains, "[i]n a republican system of government, the whole people embody authority, legitimacy, and power. In a self-consciously Christian, even Protestant, religious culture, the whole populace is the potential seedbed of the Kingdom of God, and society the setting of struggle between the forces of darkness and of light." ${ }^{, 26}$ Thus, as Americans of faith reach out to the populace to bring light in the name of their god, they necessarily find themselves in the midst of the source of all authority, legitimacy, and power in the political sphere. Confronted with such a dynamic, Professor Thomas Shaffer has stressed that "[w]e have no choice but to let our theology function in rela-

witness to and transform culture "by setting up alternative communities that they hope will draw others to Christ").

124. Peggy T. Cantwell, Response to the Paper Authored by Professor Joseph Allegretti: Lawyers, Clients, and Covenant: A Religious Perspective on the Legal Practice and Ethics, 66 FORDHAM L. REV. 1153, 1156 (1998); see also James M. Jenkins, What Does Religion Have to Do with Legal Ethics? A Response to Professor Allegretti, 66 FoRDHAM L. REV. 1167, 1169 (1998) ("My answer is "everything or nothing.' If God is the first priority in a lawyer's life-private and professional-it's everything. If not, it's nothing."); RICH MULLINS, Creed, on A LiturgY, A LEGACY, AND A RAGAMUFFIN BAND (Reunion Records 1993) ("I did not make [my faith], no it is making me."). For a discussion of the level of devotion desired by God, see BLESSED FAUSTINA KOWALSKA, Divine MERCY IN MY SOUL 442 (1987) ("Today bring to Me souls who have become lukewarm, and immerse them in the abyss of My mercy. These souls wound My heart most painfully. My soul suffered the most dreadful loathing in the Garden of Olives because of lukewarm souls.").

125. Robert M. Calhoon, Separation of Church and State, in EERDMAN, supra note 21, at 271.

126. Id.; see also SECOND VATICAN COUNCIL, GUADIUM ET SPES II 28 (1965) ("Indeed love itself impels the disciples of Christ to speak the saving truth to all men."). President Clinton testified to this relationship in his speech at New Psalmist by emphasizing to the congregation, "thank the Lord there is no Caesar in this country. The good news is there is no Caesar. The bad news is, the people who have to render have more to do. Because you pick the people who make the decisions." Clinton Speech, supra note 35 , at 2. 
tion to socioeconomic reality and power. To deny this linkage is to engage in self-deception."

One must recognize that Professors Calhoon and Shaffer acknowledge not only a mutual audience between church and state but also a symbiosis in mission. The body politic seeks to wield power legitimately. The body of faith, meanwhile, is obligated "to speak truth to power," 128 a truth that, as Professor H. Jefferson Powell has noted, is not only the truth about the faith community but also a "truth about the world." 129 The body of faith must speak this truth because theirs is not a passive, toothless God who can be intimidated in the face of injustice, but rather a God who "takes sides; who disrupts political and legal order [and] confronts legal ideology, which protects the wealth of the powerful and provides ease to the consciences of lawyers." ${ }^{130}$ Thus, the bodies of politics and faith must communicate because power cannot be wielded legitimately in the absence of truth and because God will not be silent on the subject of justice. As the Lutheran minister and martyr to Nazism Dietrich Bonhoeffer put it, "[t]he function of the Church ... is not to draw her own boundaries; but in times of crisis she must make a clear confession of her faith, and her boundaries will then be determined for her by those who reject it."131

For the religious person, the implications of failing to make public such a clear confession of faith can be profound. For example, the Hebrew prophet Ezekiel took his lead from the following divine message:

Son of man, speak thus to your countrymen: When I bring the sword against a country, and the people of the country select one of their number to be their watchman, and the watchman, seeing the sword coming against the country, blows the trumpet to warn the people, anyone hearing but not heeding the warning of the trumpet and therefore slain by the sword that comes against him, shall be responsible for his own death. He heard the trumpet blast yet refused to take warning; he is responsible for his own death, for had he taken warning he would have escaped with his life. But if the watchman sees the sword coming and fails to blow the warning trumpet, so that the sword comes and takes anyone, I will hold the watchman responsible for that person's death, even though that person is taken because of his own $\sin .{ }^{132}$

127. Thomas L. Shaffer, Faith Tends to Subvert Legal Order, 66 FORDHAM L. REV. 1089, 1099 (1998) (quoting Walter Brueggemann, Psalms 9-10: A Counter to Conventional Social Reality, in THE PSALMS: THE LIFE OF FAITH 227, 233 n.32 (Patrick D. Miller ed., 1995)).

128. Powell, Moral Tradition supra note 15 , at 11,264. For a discussion of the challenge for a Christian to speak truth to power in America given the differences in the language of Christianity and American Constitutionalism, see Randy Lee, Reflections on a Rose in its Sixth Season: A Review of H. Jefferson Powell's THE MORAL TRADITION OF AMERICAN CONSTITUTIONALISM, 32 CREIGHTON L. REV. 1205, 1226-59 (1999).

129. Powell, Moral Tradition, supra note 15, at 265 (quoting StANLEY HAUERWAS, CHRISTIAN EXISTENCE TODAY $102(1988))$.

130. Shaffer, supra note 18, at 1096; see also Rich Mullins, Awesome God, on Songs (Reunion Records 1996) ("When He rolls up His sleeves, He ain't just putting on the ritz. Our God is an awesome God. There is thunder in His footsteps and lightning in His fists.").

131. MARy Bosanquet, The Life And Death OF Dietrich BonhoefFer 176 (1968). "The question of belonging to the Church is the question of salvation. The boundaries of the Church are the boundaries of salvation." Id. at 177 .

132. Ezekiel 33:2-6. 
Even less expansive views of religion lead to the same conclusion that religion and politics inevitably intersect. For example, those who restrict the purposes of religion to saving souls and preparing people for the after-life concede that to do this, a church must seek "[t]o obtain the best conditions for achieving this in the various nation states." engage in open dialogue on contemporary conditions and, hence, intersect with the political sphere. Others who see religion as a source of cultural diversity rather than a vessel of truth also encounter this intersection. For instance, Justice William Brennan acknowledged that religious organizations are valuable to American society because they contribute "to the diversity of association, viewpoint, and enterprise essential to a vigorous pluralistic society." ${ }^{134}$ Yet, such organizations can contribute to the diversity of viewpoint essential to keeping a pluralistic society vigorous only if they can express their views on the issues of greatest importance to the community. Again this requires that they be able to engage in open discourse within the political sphere. As Senator Rick Santorum articulated this, "perhaps the only way out of the current bleak situation [in American culture] could be found in the search for what unites the various religions and cultures, in the search for common sources, principles, certitudes, aspirations, and imperatives." ${ }^{135}$ But to conduct this search, we must allow the voices to be heard.

Once we recognize that religion cannot be accurately defined in a way that keeps it neatly separate from politics, IRS restrictions on church involvement in politics must crash headlong into the Sherbert standard. ${ }^{136}$ If church religious activities intersect with what we consider to be political activity, then laws that condition a church's tax-exempt status on the church's refraining from participation in those activities force the church "to choose between following the precepts of her religion and forfeiting benefits, on the one hand, and abandoning one of the precepts of her religion." ${ }^{137}$ Such laws cannot survive absent a compelling countervailing government interest. ${ }^{138}$

Of all the IRS attempts mentioned earlier, ${ }^{139}$ the attempt to regulate statements reflecting voting records or candidates' positions on issues strikes most clearly at the heart of religion. ${ }^{140}$ When the IRS tells the Christian Coalition that it cannot isolate the positions it considers most important ${ }^{141}$ or tells Branch Ministries that it cannot use its sacred text to acknowledge its bias on certain is-

133. RHODES, supra note 119 , at 354 .

134. Walz v. Tax Comm'n of N.Y., 397 U.S. 664, 689 (1970) (Brennan, J., concurring) (allowing New York City to exempt churches from property taxes).

135. Religion Needs Voice in Public Square, Senator Says, CATH. WiTNESS, Aug. 13, 1999, at 1 (quoting Vaclav Havel).

136. See supra text accompanying notes 76-79.

137. Sherbert v. Verner, 374 U.S. 398, 404 (1963).

138. See id.

139. See supra text accompanying notes 89-92.

140. See Rev. Rul. 78-248, 1978-1 C.B. 154.

141. See id. 
sues, ${ }^{142}$ the IRS strikes at the heart of religious mission. If the church is to be the church, it cannot be controlled by the state in determining the questions it deems important and worthy of consideration. If free exercise means anything, religious organizations must be free to say "this is what matters," and the church must not be forced to hide the questions that do matter in the morass of questions that do not.

To allow faith to focus the questions of human debate was a recurring theme in the efforts of the Reverend Dietrich Bonhoeffer to rescue Germany from its slide into Nazi domination. Bonhoeffer stressed that "[i]t is of central importance that man shall ask the right question." when it is allowed to lead people to ask themselves the wrong questions. ${ }^{144}$ More recently, Professor $\mathrm{H}$. Jefferson Powell has stressed that people are united "as much [by] the problems they think important as the answers they think correct."

Throughout the Clinton era, faith traditions in America have been challenged to reconsider what questions should matter to the country. During the 1992 election, Catholics were divided by internal debate, not unlike that suggested by the Branch Ministries advertisement, over whether abortion is "a moral issue of such overwhelming importance that it dwarfs all other issues" or whether it must be considered in the context of "the nation's economic and social health as a whole." ${ }^{146}$ After the election, First Lady Hillary Clinton, in the midst of her national discussion of health care, addressed the "sleeping sickness of the soul" from which she perceived the nation was suffering. ${ }^{147}$ The handling of the President's impeachment, an issue that dominated the political scene throughout the 1998 election season and into 1999, was described by Reverend Phillip Wogaman, one of the President's spiritual advisers, as a struggle for America "to define its own soul," an effort by America "to reach deeply into the moral, spiritual and legal traditions that have formed us as a people" and then decide "which of these, law or love, must give way when they are in conflict." $" 148$

142. See id. ("The advertisements oppose the political candidacy of the particular candidate because they describe the candidate and his alleged policies in a negative manner. Further the advertisements were widely disseminated among the electorate, and concentrate on a narrow range of issues."); Revocation of Tax Exempt Status of Branch Ministries d/b/a The Church at Pierce Creek.

143. BOSANQUET, supra note 131, at 123. One might argue that for Bonhoeffer the ultimate "right" question was "Who is the Lord that I might believe in him?," $i d$., a seemingly purely religious question which has nothing to do with politics. However, such an argument would betray the essence of Bonhoeffer's life. For him, this question had everything to do with everything, including politics. In fact, it asks, much as did the Branch Ministries ad, "How can I vote for someone whose teachings are not those I claim to worship above all else?"

144. See id. at 116.

145. POWELl, Moral Tradition, supra note 15 , at 30.

146. Robert J. Hutchinson, Catholics and the Election, CATH. TwIN CIRCLE, Nov. 1, 1992, at 10.

147. Joan Connell, Spiritual Politics: First Lady Preaches Scholar's Theory on Need for Human Connectedness, HARRISBURG PATRIOT-NEWs, June 6, 1993, at D1.

148. Lefevere, supra note 54, at 7. 
It is difficult in this context to deny that a major theme in American religious and political discourse is defining what questions must take precedence in national discourse. This is unlikely to change in the near future. As Reverend Wogaman maintains, the dominant issues on America's horizon are the disconnect between sex and love, the role of pornography, the right to privacy, and the degree to which "mean-spiritedness" and attack ads contribute to our political character. ${ }^{149}$ They are issues that defy neat compartmentalization into either the religious or political realms. In addition, much of the debate must address which issues are more important, and which must be addressed first to set the context for addressing others. In Branch Ministries, DOJ argued that the IRS wanted to avoid being entangled in questions of church motivations and creeds. ${ }^{150}$ With such a desire, one would expect the IRS to refrain from regulating the kinds of questions churches address and the context in which they address them.

Related to this are IRS attempts to regulate when religious organizations raise concerns or questions that overlap with political issues. The IRS would attempt to silence religious organizations during election seasons, ${ }^{151}$ but this effectively instructs religious organizations not to speak at precisely those times when people are most likely to listen. For religious organizations that believe their mission is to harvest from the whole populace ${ }^{152}$ or those that consider themselves called to be "the light of the world," 153 this restriction requires that they choose between abandoning a tenet of their faith or losing the benefits of tax-exempt status. ${ }^{154}$ Perhaps even more problematically, the current presidential campaign season with its early primaries and earlier straw polls, ${ }^{155}$ suggests that America may eventually evolve into a political community where the election season never ends and, hence, religious organizations can never speak on issues of public concern. ${ }^{156}$

Less clear is whether religion is necessarily burdened by IRS attempts to curtail "statements on behalf of or in opposition to a candidate for public of-

149. Id. One might also add legalized gambling and drug use, which also have both religious and political aspects as well.

150. Defendant's Brief, supra note 67, at 17. This desire is understandable given Supreme Court decisions indicating that such entanglement would violate the Establishment Clause. See, e.g., Swaggart Ministries v. Board of Equalization of Cal., 493 U.S. 378, 393 (1990) (discouraging state regulation that is "excessive"" and calling for "official and continuing surveillance") (quoting Walz v. Tax Comm'n of N.Y., 397 U.S. 664, 674-75 (1970)).

151. See supra text and accompanying note 82.

152. See supra text accompanying notes 126-130.

153. Matthew 5:14.

154. The apostles Peter and John felt they had been asked to make such a choice when the officials of the Sanhedrin ordered them not to speak of the events surrounding the execution of Jesus. See Acts 4:18-20.

155. See David S. Broder, GOP Field May Thin as Rivals Criticize Bush, PITT. Post-GAZETTE, Aug. 16, 1999, at A1 (discussing the effects of Iowa Straw Poll, including the withdrawal of Lamar Alexander from race for the Republican Presidential nomination).

156. This problem might be compounded by the possibility of restrictions on comments regarding incumbents who are not candidates for re-election. See Scott W. Putney, The IRC's Prohibition of Political Campaigning by Churches and the Establishment Clause, FLA. B.J., May 1990, at 27, 28. 
fice, ${ }^{157}$ including statements perceived as inflammatory or arising out of strong emotional feelings. ${ }^{158}$ It can be argued that some "inflammation" or strong emotional feeling is inevitable with discussion of issues that cut to the core of who we are. ${ }^{159}$ On the other hand, religious organizations, themselves, have been known to stress the need to discuss issues in a way "which avoids caricature and over-dramatization." 160 One might also argue that religion is more about evaluating the morality of conduct than evaluating the morality of particular individuals. Certainly the case could be made for this in the context of faiths in the Christian tradition. ${ }^{161}$ Yet one cannot necessarily say that when the Reverend Jesse Jackson characterizes Newt Gingrich and Trent Lott as lobbyists for Hell, or Representative Dennis Kucinich leads the faith-filled in a cry of "The Democratic ticket. Say Amen!,"162 they are not acting out the calling of their religion. $^{163}$

We need not resolve whether a particular faith tradition might be burdened by restrictions on inflammatory language and evaluations of individuals. Even if these restrictions burdened religion, such burdens need to be considered within the context of the relevant governmental interest. As we shall see, the issues relating to these restrictions are better considered in the governmental interest context than in the religious liberty context. ${ }^{164}$ This may suggest that ultimately the Supreme Court should settle its free exercise standard at an intermediate level between Sherbert ${ }^{165}$ and Smith, ${ }^{166}$ but the resolution of that struggle transcends the scope of this article.

The IRS acts wisely to the extent that it relies upon the "average person could only conclude" standard ${ }^{167}$ in evaluating whether the statements of religious organizations encroach upon the political realm. This standard resembles

157. See supra text accompanying note 81 .

158. See supra text accompanying note 83 .

159. For example, the apostle Paul's discussions of issues of his faith always yielded passionate responses though not always the one Paul desired. See, e.g., Acts 9:23-25 (plot to murder Paul in Damascus), 13:50-52 (expulsion of Paul from Antioch), 14:5-6 (attempt to Stone Paul in Iconium), 14:19-20 (stoning of Paul in Lystra), 16:25-39 (imprisonment of Paul in Philippi), 17:8-14 (pursuit of Paul in Thessalonica and Berea), 19:23-20:1 (rioting in Ephesus), 23:20-35 (plot to murder Paul in Jerusalem).

160. No to Measure 9, CATH. TwIN CIRCLE, Oct. 18,1992, at 17 (discussing the Catholic Church's efforts in Oregon to defeat a measure in Oregon banning affirmative action provisions based on sexual orientation).

161. Matthew 7:1 ("Stop judging that you may not be judged."); id. 19:17 (Jesus explaining, "There is only one who is good."); Lefevere, supra note 54, at 7 (Clinton spiritual advisor Reverend Wogaman saying, "[N]o one can say that [I'm a better man than you are]-all are in need of forgiveness, and repentance can take a lifetime.").

162. See supra text accompanying notes 52-58; see also Lefevere, supra note 54, at 7 (Reverend Wogaman assuring "The American people will be in for a confirmation of their best perceptions of [the President].").

163. See 1 Kings 18:18 (Elijah saying to King Ahab, "It is not I who disturb Israel, but you and your family, by forsaking the commands of the Lord and following the Baals"); Luke 7:28 (Jesus proclaiming, "I tell you, among those born of women, no one is greater than John [the Baptist]").

164. See infra text accompanying notes $248-272$.

165. Sherbert v. Verner, 374 U.S. 398 (1963).

166. Employment Div., Dep’t. of Human Resources of Or. v. Smith, 494 U.S. 872 (1990).

167. See supra text accompanying note 88 . 
the innocent construction rule sometimes applied in defamation contexts. ${ }^{168} \mathrm{Al}-$ though the Supreme Court has yet to embrace innocent construction as necessary to protect free speech in the defamation context, it has only refrained from doing so because defamation law contains other constitutional requirements designed to protect speech. ${ }^{169}$ Innocent construction can be more easily justified in this context because no elaborate protections are in place with respect to religion. The question in the Branch Ministries advertisement- "How then can [Christians] vote for Bill Clinton?"-illustrates the role innocent construction can play in this context. ${ }^{170}$ Normally, the question could be understood rhetorically as a statement directly in opposition to President Clinton. However, innocent construction requires that because the average reader could also understand the statement as a question designed to invite discussion about the candidacy, the law must accept the more innocent meaning rather than the partisan one. As demonstrated earlier, the position of religious organizations is on more solid ground when they frame issues and inject questions than when they judge individuals. $^{171}$

Thus, there is a broad notion of religion, consistent with the President's approach to campaigning, but burdened by IRS and DOJ efforts to keep partisan politics separate from religion. Yet the analysis does not end here. We must now question whether the positions of the IRS and DOJ might still be defended by the presence of one or more legitimate governmental interests.

IV

\section{THE GOVERNMENTAL INTEREST IN AN INDEPENDENT RELIGIOUS CONSCIENCE}

In Branch Ministries, DOJ advanced two governmental interests to justify the IRS ban on partisan political activity. DOJ first argued that the federal government had a "compelling interest at stake [in] ensuring that tax-deductible monies obtained from third-party contributions not be used by religious organizations for partisan political activities." ${ }^{172}$ Second, the government also had a "compelling interest in maintaining a tax system that is applied uniformly and is

168. See, e.g., Chapski v. Copley Press, 442 N.E.2d 195 (Ill. 1982). Innocent construction is not the same as the "rational interpretation" the Court discussed in Masson v. New Yorker Magazine, Inc. 501 U.S. 496, 518-20 (1991). While innocent construction seeks to give the most innocent meaning possible to what a speaker has said, rational interpretation considers whether the speaker's statement reflects a rational interpretation of his sources.

169. See New York Times v. Sullivan, 376 U.S. 254 (1964) (creating "actual malice" protection in defamation suits by public official); Gertz v. Robert Welch, Inc., 418 U.S. 323 (1974) (extending the actual malice standard to suits by public figures and granting other protections to the media); Philadelphia Newspapers, Inc. v. Hepps, 475 U.S. 767 (1986) (placing the burden of proving falsity on private figure plaintiffs in defamation suits involving press defendants and issues of public concern).

170. See supra text accompanying note 28.

171. See supra text accompanying notes 140-163.

172. Defendant's Brief, supra note 67 , at 15. 
free of endless exceptions based upon a wide variety of religious beliefs." ${ }^{173}$ The court in Branch Ministries, meanwhile, acknowledged simply "an overwhelming and compelling governmental interest" in "guaranteeing that the wall separating church and state remain high and firm."

Ultimately, neither DOJ nor the court relied on an interest that reflected the historical and essential purpose for keeping church and state separate. The primary governmental interest can never be to guarantee that the state will not have to listen to the voice of the church; rather, as discussed above, the essential governmental interest is to guarantee that the church retains a voice worth listening to. America needs a church independent enough to act as a conscience in national discourse. Without such an independent conscience, law, as Professor Powell points out, threatens to destroy not only itself but all who encounter it:

Loyalty to the law as a self-contained system is ultimately destructive, of the lawyer and of the law. It becomes forgetful of the weightier matters of the law: justice, mercy, and faith. It becomes a betrayal of the wider loyalties to which we are summoned, to our brothers and sisters, to God. ${ }^{175}$

Rabbi and Professor Lawrence Hoffman similarly emphasizes the need for legal power to feel accountable to something beyond the law: "I can think of nothing that will help lawyers more than to keep forever before them the Jewish horror that society might sink once again to the level of the generation of the flood because it concludes leit din v'leit dayyan, 'There is neither judge nor justice.", 176

History attests to Professor Hoffman's observation. In the early Ottoman Empire, the Turks demonstrated a "relative tolerance" of other religious and ethnic communities based in part on a genuinely religious spirit, but as this religion was contaminated with nationalistic fervor around the time of the First World War, "genocidal massacres became an instrument for the achievement of

173. Id. at 16. DOJ argued that such a uniform system also benefited religious organizations because it would minimize "IRS scrutiny of their operations and beliefs." Id. However, that benefit is merely illusory. If the restriction on partisan political activity was lifted when it burdened religious exercise, religious organizations would have three options: They could refrain from political activity, remain tax-exempt, and avoid IRS scrutiny; engage in political activity, voluntarily give up their taxexempt status, and avoid IRS scrutiny; or engage in political activity, seek to retain their tax-exempt status, and explain their religious beliefs to the IRS.

Under the current IRS approach, religious organizations do not have the third option. It is hard to imagine how DOJ perceived this loss of an important option as a benefit to religious organizations; yet, the language from Swaggart v. California Equalization Board, 493 U.S. 378, 396-97 (1990), suggests that the Supreme Court fell into the same trap.

On the lighter side of this dilemma, it is curious that DOJ assumed that religious organizations would feel threatened by IRS scrutiny of their beliefs. Some of these organizations might simply perceive the third option as an opportunity to evangelize IRS agents.

174. Branch Ministries v. Rossotti, 40 F. Supp. 2d 15, 25 (D.D.C. 1999) (quoting Christian Echoes National Ministry Inc. v. United States, 470 F.2d 849, 857 (10th Cir. 1972)).

175. H. Jefferson Powell, Loyalty to the Law: Politics and the Practice of Public Lawyering in the United States, 72 NoTRE DAME L. REV. 78, 88 (1995).

176. Lawrence A. Hoffman, Response to Joseph Allegretti: The Relevance of Religion to a Lawyer's Work, 66 FORDHAM L. REV. 1157, 1165 (1998). 
a homogeneous nation-state." ${ }^{177}$ Throughout much of Europe, the Vatican and the Pope have been perceived as a conscience for nations and a source of healing and mediating power between nations. ${ }^{178}$ Yet, critics also point to the failure of the Catholic Church to fulfill this capacity during World War II, ${ }^{179}$ a time when Italian loyalties within the Vatican and the Vatican's dependence on the Italian state for "essential supplies, food, water, and electricity" prevented the Church from confronting Fascism as it otherwise might have. ${ }^{180}$ Meanwhile, in Germany, Hitler recognized that he needed to reduce the German Protestant Church to "a specialized propaganda agency" and to neutralize the Catholic Church "to pursue his political policy unmolested." "As the Reverend Dietrich Bonhoeffer witnessed the Church in Germany falling increasingly under Hitler's influence both politically and spiritually, he observed that the Church's role as moral compass was turned on its head: No longer did the nation ask, as King Jehoshaphat of Judah had, for God to respond to the King's prayers with God's plans; ${ }^{182}$ instead, the nation's plans became objects of God's endorsement:

Our plans and programmes do not melt into prayers, instead they go on to become, amid the blaze of enthusiasm, shining standards and banners proclaiming the virtue of our cause. Now determination does not change into despondent humility, but into the irresistible claim to our own power and our own audacity. No, on the contrary, now it is the prayers that turn into programmes, the requests into orders, and finally at the end of the programme, we must append the name of God, so that he too may be pressed into the service of the programme, of the clever plan, of our own determination. $^{183}$

After World War II, communism followed Hitler's example by imposing loyalty requirements on churches, pressuring churches for their endorsement, and imprisoning religious figures who measured the oppressive policies of the state with their divine and independent yardstick. ${ }^{184}$ Critical to ending that regime were Pope John Paul II's appeals of conscience in Poland ${ }^{185}$ and the responses those public appeals generated in other nations. ${ }^{186}$

177. BRANimir ANZUlovic, HeAvenly SERbia: From Myth to GENOCIDE 180-81 (1999).

178. See RHODES, supra note 119 , at 11-12, 70-71.

179. See id. at 11-12.

180. Id. at 356. Rhodes stresses that the Catholic Church did take stands against Fascism during World War II, stands which showed its willingness to accept its responsibility as an independent moral conscience. See id. at 288-91.

181. BoSANQUET, supra note 131, at 122 . When Hitler failed to enlist the Church as an instrument of propaganda, he sought to silence the Church. See id. at 182.

182. See 2 Chronicles 20:12 (Jehoshaphat's meeting with his advisors dissolves into the prayer, "We are at a loss what to do, hence our eyes are turned toward you.").

183. BosANQUET, supra note 131, at 96 (quoting Bonhoeffer). As a leader of the Confessing Church in Germany, Bonhoeffer actively organized German religious leaders to oppose publicly antiSemitic policies. See, e.g., id. at 128 (Bonhoeffer working to oppose Hitler's efforts to exclude those of Jewish descent from governmental employment).

184. Werenfried VAN StraAten, They CAll Me THE BACON PrIEST 210-11, 225-26 (1989).

185. See Vera Haller, Albright, Pope Discuss Cuba, Eastern Europe; Cordial Meeting Despite Differences, WASH. POST, Mar. 8, at A26.

186. See Eric Black, In Minneapolis, Bennett calls on conservatives to stand firm, STAR-TRIB., May 22, 1999, at 4A; Patrick Marrin, Nonviolence is possible, and no longer just an option, NAT'L CATH. 
Most recently, atrocities in the Balkans have been attributed to the failures of churches, again weakened by fervent nationalism, to act as a moral check on governmental policies. In particular, the Serbian Orthodox Church has received criticism for being so closely connected with its state and nation, both politically and financially, that it lost track of the gospel. ${ }^{187}$ As Branimir Anzulovic observed, the very people who needed to act as "the moral conscience of the nation and condemn the crimes committed in the attempt to create a Greater Serbia [were] instead ardent nationalists and inciters of xenophobia." It was only after 300,000 deaths in Bosnia, Croatia, Kosovo, and Serbia, that the Serbian Orthodox Church asserted itself as an independent voice of conscience and called for the resignation of Slobodan Milosevic, a key event in resolving "the awful drama of Serbia in the 1990's." 189 When the call finally did come from the church, it came powerfully. Patriarch Pavle, head of the Serbian Orthodox Church exclaimed,

If the only way to create a greater Serbia is by crime, then I do not accept that, and let that Serbia disappear. And also if a lesser Serbia can only survive by crime, let it also disappear. And if all the Serbs had to die and only I remained and I could live only by crime, then I would not accept that. It would be better to die..$^{190}$

America, too, has demonstrated the same necessity for an independent national religious conscience throughout its history. While the nation's two greatest moral triumphs, the end of slavery ${ }^{191}$ and state-sanctioned segregation, ${ }^{192}$ have roots in the uncompromising efforts of religious organizations to serve as the national conscience, other periods have been marked by moral failures when churches have become lost in the American dream. In fact, the need for an independent moral conscience in America has been clear from the time the popes granted authority over New World ecclesiastical matters to a Spanish government more supportive of its military commanders' "ruthless disregard for physical life" than of the labors of the Friars for the eternal life of Native Americans. ${ }^{193}$ When the Puritans failed to preserve an independent religious

REG., Apr. 30, 1999, at 12 ("The fall of communism and the end of the Cold War was likewise triggered by nonviolent resistance in Poland and Czechoslovakia, and by a pope who had no divisions but who had an inspired sense of the pulse of history."); Tammeus, supra note 119, at L3 (Pope John Paul II "quite rightly can take considerable credit for the fall of communism in his native Poland and then in eastern Europe.”). Accord JOSYP TERELYA WITH MICHAEL H. BROWN, WITNESS TO APPARITIONS \& PERSECUTION IN THE USSR 316-24 (1991) (discussing Catholic efforts for Ukranian independence).

187. See AnZulovic, supra note 177, at 6; Georgie Anne Geyer, "Milosevic is Mad": Serbian Priests Take Belated Steps Toward Redemption, HARRISBURG PATRIOT-NEWS, July 5, 1999, at A8.

188. ANZULOVIC, supra note 177, at 177.

189. Geyer, supra note 187, at A8.

190. Id.

191. See EERDMAN, supra note 21, at 261 (describing the abolitionist impact of Harriet Beecher Stowe's UNCLE TOM's CABIN (1852)); see also Ellis M. West, The Free Exercise Clause and the Internal Revenue Code's Restrictions on the Political Activity of Tax-Exempt Organizations, 21 WAKE FOREST L. REV. 395, 396 (1986).

192. See Wesley A. Roberts, The Black Revolution and the Churches, in EERDMAN, supra note 21, at 447 ("The revolution began in the black church under the leadership of a black Baptist clergyman. It received its inspiration from the hymns, sermons, and charismatic leadership of the church, which became the meeting place for marchers.").

193. EERDMAN, supra note 21, at 12-13. 
voice in the Massachusetts colony, instead allowing the interests of the church to become too tightly bound to the success of the colony, the result was a disrespect for the land rights of Native Americans and the persecution of religious and political dissent. ${ }^{194}$ The pre-Civil War Church also failed the nation as an instrument of peaceful reconciliation because its leaders too often allowed their geographic and political loyalties to shape their social and moral vision. ${ }^{195}$

After the Civil War, Protestant churches became seduced by the idea of being America's church, and thereby lost their independent vision. They became increasingly content to provide guidelines for good citizenship while losing their ability to speak boldly where conscience was required. ${ }^{196}$ The result was the "Gilded Age," a period "marked by the assassination of two presidents and the impeachment of another, a stolen election, and a reign of rampant political and business corruption and greed." ${ }^{197}$ It was a period when politicians "talked about virtue and vice as a man who is colour-blind talks about red and green," and when the religious and ethical concerns of the business world simply yielded to more "practical considerations." America "effectively free from internalized moral restraints" neath a "veneer of evangelical Sunday-school piety.",200

Dorothy Day, co-founder of the Catholic Worker movement and a prospective Catholic saint, described a church and culture similarly lost in the 1920s, but this time the church was won over not by appeals to its ego but by appeals to its purse. $^{201}$ Increasingly churches accepted state aid, and as a result, had to render more, as the saying goes, unto the state. ${ }^{202}$ These religious organizations "came under the head of Community Chest and discriminatory charity, centralizing and departmentalizing, involving themselves with bureaus, buildings, red tape, legislation, at the expense of human values."203 Ms. Day found her own Catholic Church all too voiceless in such an environment. ${ }^{204}$ She was appalled by the ugliness in a world that sought to label itself Christian. ${ }^{205}$

194. See George M. Mardsen, Were American Origins "Christian"?, in EERDMAN, supra note 21, at 151.

195. See EERDMAN, supra note 21, at 262.

196. See id. at 280-81.

197. Id. at 280 .

198. HenRY ADAMS, DemOCRACY (1980), quoted in Mardsen, supra note 194, at 287.

199. EERDMAN, supra note 21, at 287.

200. Id. at 280 .

201. See Dorothy Day's Abortion Not Impediment to Sainthood, CATH. WITNESS, Oct. 23, 1998, at 12 (reflecting the views of Cardinal O'Connor of New York). See generally ROBERT COLES, DoRothy DAY: A RADiCAl DeVotion (1987); David L. Gregory, Dorothy Day's Lessons for the Transformation of Work, 14 HOFSTRA LABOR L.J. 57 (1996) (claiming that many people within the church believe Day to be a Saint)

202. Matthew 22:21 (Christ instructing "Render therefore unto Caesar the things which are Caesar's; and unto God the things that are God's").

203. DOROTHY DAY, THE LONG LONELINESS 151 (1997).

204. Id.

205. Id. at 4 . 
These examples have shown that faith can call a nation to a goodness that transcends pragmatism, ${ }^{206}$ and that a nation has an interest, perhaps even a compelling interest, in allowing religious organizations the opportunity to do so. $^{207}$ Faith, however, can make a nation strive for morality only if it can remain independent of governmental influence. Faith must remain separate from the culture, from its wisdom, myths, and reality, so that it may speak meaningfully to the culture. ${ }^{208}$ In fact, among America's founding fathers, it was Roger Williams and William Penn, the most independently faith-centered of the group, who "did the most to make [the] American polity viable." 209 As theologian John Howard Yoder said, "[o]ne can change government best if one is most independent of it." 210

Such independence does not come easily. From a Nazi prison cell, Dietrich Bonhoeffer very poignantly described the difficulties of guiding an independent church through partisan political waters:

We have been drenched by many storms; we have learnt the arts of equivocation and pretense; experience has made us suspicious of others and kept us from being truthful and open; intolerable conflicts have worn us down and even made us cynical. Are we still of any use? What we shall need is not geniuses, or cynics, or misanthropes, or clever tacticians, but plain, honest, straight-forward men. Will our inward power of resistance be strong enough, and our honesty with ourselves remorseless enough for us to find our way back to simplicity and straight-forwardness? $?^{211}$

If a religious organization is to seek to serve as an independent conscience in America, then it must remember four points: First, it speaks as only one voice among many; second, it must communicate in a language the American public can understand; third, it must accept that the American public may not listen; and, fourth, it must not depend on the use of force to impose its views.

The first of these points should be easily understood by all American faith communities, since Judeo-Christian prophets have often been required to speak

206. SHAFFER, supra note 18 , at 25 ("[M]oral values are not dependent upon cultural consensus about their existence or about how successful one's life will be if lived in conformity to them.") (quoting John Howard Yoder)).

207. As social commentator Aldous Huxley put it:

What can the politicians do for their fellows by actions within the political field, and without the assistance of the contemplatives? The answer would seem to be: not very much. Political reforms cannot be expected to produce much general betterment, unless large numbers of individuals undertake the transformation of their personality by the only method which really works - that of the contemplatives. Moreover, should the amount of mystical, theocentric leaven in the lump of humanity suffer a significant decrease, politicians may find it impossible to raise the societies they rule even to the very moderate heights realized in the past.

Aldous Huxley, Politics and Religion, in COLLECTED ESSAYs 268, 277 (1964).

208. See Shaffer, supra note 127 , at 1089.

209. SHAFFER, supra note 18, at 9 (quoting John Howard Yoder).

210. Id. (quoting John Howard Yoder). In Mistretta v. United States, the Supreme Court similarly acknowledged its own need to remain independent. See Mistretta v. United States, 488 U.S. 361, 407 (1989). "The legitimacy of the Judicial Branch ultimately depends on its reputation for impartiality and nonpartisanship. That reputation cannot be borrowed by the political Branches to cloak their work in the neutral colors of judicial action." Id.

211. BOSANQUET, supra note 131, at 248. 
as one voice among many elsewhere, ${ }^{212}$ and other faiths have had to function as minority voices in America. The importance of speaking in a language the public can understand is best understood, meanwhile, in the context of a comment by John Howard Yoder about the way some might use religious discourse to exclude others from public debate:

[To say] let religions try to impose their views, since the secularists do it, misses the important difference; when a secular powerbearer claims to be saving me he has to give reasons the whole polity can understand and vote on. He does not call on God to quiet his opposition. The secularist can be called to account. So can the theist who accepts the pluralistic policy. But not the theist who excludes his/her adversary from the hermeneutical circle. If I am the excluded adversary, I don't like the oppression. If I am a theologian, I don't like the abuse of the name of God. ${ }^{213}$

Yoder also observed that when faith communities merely tell bearers of power in America that they are bad people and then work to circumvent power rather than communicate with these powerbearers, those faith communities only stimulate the bearers of power to make matters worse and circumvention more difficult. ${ }^{214}$

The third point does not suggest that people of faith do not hope to be heard. As Yoder stressed, "there is nothing about the ethics I teach which ever accepts a priori not being heard by the wider world. We always assume that, the truth we proclaim being true, everybody ought to hear it and if they heard it and listened their lives would be better." ${ }^{215}$ Yoder added, however, "What we [also] accept is that, a posteriori, we can go on living with the fact that we will not be heard." 216

The fourth point is a result of the recognition that once a faith community accepts state force as the best avenue to impose its views, it embraces the very kind of state entanglement that undermines the independence it should be seeking to preserve. In addition, when faith communities rely on force for per-

212. See, e.g., 1 Kings 18:21-40 (Elijah speaks to the people from among the 450 prophets of Baal); 1 Kings 22:1-28 (The prophet Micaiah speaks from among the 400 deceived prophets of Israel); Jeremiah 28 (The prophet Jeremiah contends with the false words of Hananiah).

213. SHAFFER, supra note 18, at 8 (quoting John Howard Yoder); see also Acts 2:5-6 (people of all nations hear the Church speaking to them in their own language). For a secular discussion arriving at this conclusion, see Robert L. Lipkin, Religious Justification in the American Communitarian Republic, 25 CAP. U. L. REV. 765, 785-87 (1996) (distinguishing between those religious precepts that can be translated into the "American deliberative discourse" and those that cannot). But see Steven Shiffrin, Religion and Democracy, 74 NOTRE DAME L. REV. 1631, 1632-33 (1999) (maintaining that generally legal scholarship "is overly critical about the role that religious speech may properly play in democratic life").

214. See SHAFFER, supra note 18, at 17. For a further discussion of the need for faith communities to speak to powerbearers but the difficulty of those communities doing so, see Lee, supra note 128, at 1226-59.

215. SHAFFER, supra note 18, at 34 (quoting John Howard Yoder).

216. Id. Yoder explained this latter acceptance in the following terms: "I believe in trying to follow a man who was ultimately defeated in terms of human social process; I have to be much more ambivalent about the meaning of words like 'useless." Id. at 16; see also John 15:18 ("If the world hates you, remember it hated me first"); Matthew 10:14 ("Whoever will not receive you or listen to your words-go outside that house or town and shake the dust from your feet."). 
suasion, they call up historical images, like those noted earlier, ${ }^{217}$ that invite fear and suspicion in the public square and, thus, damage the faith community's credibility. As Professor Powell points out,

[n]on-Christians are right to fear Christian social power. They are absolutely right. Christian social power has been used again and again in history in evil ways. The starting point for Christian truthfulness and Christian social witness is to recognize that and to be aware of it, and to let that fact shape our action. ... We have to deal with the rightful fears and concerns of non-Christians, the non-Christians who are our brothers and sisters and members of the political communities in which God has placed us. $^{218}$

One can trace the notion, that the government's interest in keeping separate church and state is not to keep religion out of politics, but to preserve religion as an independent voice in politics, to those individuals whom President Clinton considers to be most responsible for "laying the foundation for the great tradition of religious liberty that would ultimately find expression in the First Amendment to the Constitution." ${ }^{219}$ These individuals are Roger Williams, founder of Rhode Island, and William Penn, founder of Pennsylvania. ${ }^{220}$ As John Howard Yoder noted, neither Williams nor Penn were secularists, pluralists, or individualists; rather, each was a "Christian theocrat" who believed the order "God wants in the civil realm does not govern belief or assembly.",221 Williams founded Rhode Island after Massachusetts expelled him for trying to serve as an independent religious conscience in a colony where church and state had chosen to be intimately intertwined. ${ }^{222}$ In Rhode Island's charter, Williams wrote that the colony would pursue its intentions "in holy Christian faith," 223 yet, he grounded in that faith "a full liberty in religious concernments." 224 Consistent with his defiant attitude, Williams created a colony committed to being answerable to Christian conscience but aware that "civil power has no jurisdiction over the conscience of its citizens." 225 As a warning of the necessity of keeping the colony's faith conscience independent of governmental entanglement, Williams stressed that "there are great dangers of overestimation of a nation's virtue when it regards itself as an extension of God's Kingdom.,"226

217. See supra text accompanying notes 177-205; see also Edwin S. Gaustad, Roger Williams, in EERDMAN, supra note 21, at 48 ("In the whole history of mankind, most of the bloody chapters have been written by nations using force in matters of religion.").

218. Conversations, H. Jefferson Powell on the American Constitutional Tradition, 72 NOTRE DAME L. REV. 11, 66 (1996); see also SHAFFER, supra note 18, at 2 ("The reason we got into the box where assertions based on faith are especially constricted is the long history of the people who made assertions based on faith coercively."” (quoting John Howard Yoder)).

219. Religious Freedom Day, supra note 106.

220. See id.

221. SHAFFER, supra note 18, at 4 (quoting John Howard Yoder).

222. See Gaustad, supra note 217, at 47-48.

223. Mark A. Beliles \& Stephen K. MCDowell, AmericA's Providential History 87

(1994) (quoting the Royal Charter of Rhode Island).

224. Id.

225. Id.

226. MARSDEN, supra note 194, at 150, 151. 
William Penn, the President's other preeminent designer of religious liberty, expressed views very similar to Williams on the issue. Penn considered his Pennsylvania colony a "Holy Experiment" serve true Christian and civil liberty in opposition to all unchristian licentious and unjust practices.",228 Penn, a "compassionate humanitarian, mystic, theologian, and profound political theorist,"229 recognized that governments need to be guided by faith, just as people do. Yet, he recognized that faith had to be independent of government to be effective and granted "unprecedented freedom of religion to anyone who believed in one God."230

Subsequent events bear out President Clinton's belief that Penn and Williams established the foundation for the proper relationship between faith and government in America and, therefore, still merit our attention today. For example, at the framing of the Constitution, both "rationalists" such as Madison and Jefferson ${ }^{231}$ and Protestants such as Baptist minister Isaac Backus held the

227. EERDMAN, supra note 21, at 58.

228. BELILES \& MCDOWELl, supra note 223, at 90 (quoting Pennsylvania's Frame of Government).

229. EERDMAN, supra note 21, at 58.

230. Id. One can even today find support for Williams's and Penn's belief that Christianity offers a fertile ground for tolerance of diverse religious beliefs. Mother Teresa of Calcutta both expressed and exemplified this view in modern life:

The same loving hand that has created you has created me. If he is your father, he must be my Father also. We all belong to the same family. Hindus, Muslims and all peoples are our brothers and sisters. They too are the children of God.

Our work among the Hindus proclaims that God loves them, God has created them, they are my brothers and sisters. Naturally I would like to give them the joy of what I believe, but that I cannot do; only God can. Faith is a gift of God, but God does not force himself.

Christians, Muslims, Hindus, believers and nonbelievers have the opportunity with us to do works of love, have the opportunity with us to share the joy of loving and come to realize God's presence. Hindus become better Hindus. Catholics become better Catholics. Muslims become better Muslims.

MOTHER TERESA, WORDS TO LOVE BY 35 (1983).

231. Calhoon, supra note 125 , at 272. The characterization of Madison and Jefferson as "purely rationalists" oversimplifies these men. Judge John Noonan describes Madison as someone who sought to "follow Jesus in public life" and who seasoned "his thinking with a little divinity," and certainly not as "an enemy of serious religion." JOHN T. NOONAN, JR., THE LuSTRE OF OUR COUNTRY 66 (1998). Many of his closest friends were people who integrated faith and secular occupations, JOHN EIDSMOE, CHRISTIANITY AND THE CONSTITUTION 96 (1990), and even his religious critics acknowledged Madison to be a church-goer. Id. at 101, n.20. Madison greatly admired William Penn and the notion of religious liberty that Penn had nurtured in Pennsylvania, EDWIN S. GAUSTAD, FAITH OF OUR FATHERS: RELIGION AND THE NEW NATION 37 (1987), and believed, like Roger Williams, that "reason, not power, was the only legitimate ally of religion." Id. at 37; see also Timothy L. Hall, Roger Williams and the Foundations of Religious Liberty, 71 B.U. L. REV. 455, 505-12 (1991) (reflecting similarity of Madison's views to those of Williams).

Jefferson has been characterized as anti-Christian. See, e.g., IsAaC KRAMnICK \& R. LAURENCE MoOre, The Godless COnstitution: The CASE AgAinst Religious CorReCTNEss 108 (1996) (reporting the views of famous Connecticut Civil War era preacher Horace Bushnell). However, he passionately embraced Jesus as "the greatest teacher of moral truths that ever lived," even as he struggled with the reality of the miracles reported in the Bible. Id. at 100. Jefferson was a thoughtful reader of the Bible and refused to answer those who questioned his faith, in part, because he felt he was accountable only to God for his beliefs, see id. at 100-01, and in part because an answer would suggest that his inquisitor had a right to ask. See GAUSTAD, supra, at 47.

Ultimately, Jefferson's reservations with Christianity were not so much with Christ but with those who "corrupted the pure religion of Jesus." Id. Jefferson rejected clergy "interested not in truth but 
notion that the moral vision necessary to guide the state must come from a conscience independent of the state. ${ }^{232}$ In this light, Madison sought to maintain a separation between government and religion, ${ }^{233}$ and a "tight-lipped silence on religion" is fairly attributed to him. ${ }^{234}$ Yet, Madison was also someone whose view of law and government was influenced by his Christian religion, and his arguments on issues of public policy, including separation of powers, slavery, ${ }^{235}$ and church-state interaction, both drew on and reflected his faith. ${ }^{236}$ Madison also convinced religious figures to lobby, in twentieth century terms, the Virginia legislature in opposition to Patrick Henry's bill "Establishing a Provision for Teachers of the Christian Religion." ${ }^{, 37}$ Furthermore, there is evidence that Madison invited Baptist clergy members to rally their followers to vote for him

only in wealth and power" and clergy who would enlist the aid of the state to force "their impious heresies" down the throats of the people, especially when no rational person would swallow them. Id. Thus, Jefferson is perhaps only one step behind Catholic social activist Dorothy Day, who said:

I loved the Church for Christ made visible. Not for itself, because it was so often a scandal to me. Romano Guardini said the Church is the Cross on which Christ was crucified; one could not separate Christ from His Cross, and one must live in a state of permanent dissatisfaction with the Church.

DAY, supra note 203, at 149-50; see also ROBERT COLES, HARVARD DIARY: REFLECTIONS ON THE SACRED AND THE SECULAR 157 (1989)(quoting Guardini).

232. See Calhoon, supra note 125, at 272; see also al-Hibri, supra note 120, at 1131 (arguing that the Constitution originally sought to be neutral toward rather than averse to religions). For a more detailed discussion of the Protestant role in the framing of the Constitution, see POWELL, MORAL TRADITION, supra note 15, at 67-74.

233. See Marci A. Hamilton, Religion and the Law in the Clinton Era: An Anti-Madisonian Legacy, LAW \& CONTEMP. PROBS. 359, 361-63 (Winter/Spring 2000); see also EIDSMOE, supra note 231, at 10512; GAUSTAD, supra note 231, at 38-44, 50-58; NOONAN, supra note 231, at 69-91.

234. EIDSMOE, supra note 231, at 101.

235. See id. at 102-04.

236. Memorial and Remonstrance Against Religious Assessments is the best example of Madison's use of the Christian argument in the context of political consideration of issues of church and state. There, Madison relied "heavily on religious arguments about the primacy of religious duties and the worthlessness of coerced belief" to defeat Patrick Henry's proposal before the Virginia legislature "Establishing a provision for Teachers of the Christian Religion." Thomas C. Berg, Religion Clause AntiTheories, 72 Notre DAME L. REV. 693, 730 (1997). Madison argued that Christianity does not need state support both because of its popular appeal due to its "innate excellence" and because it "enjoys the "patronage of its Author." EIDSMOE, supra note 231, at 107. He also argued that because God had created in all people "a freedom to embrace, to profess, and to observe the Religion which we believe to be of divine origin, efforts to impose even Christianity violated that freedom and were offensive to God. EIDSMOE supra note 231, at 107. The document ended with a prayer, one that "should not be read as a polite bow to a distant deity." NOONAN, supra note 231, at 74.

Judge Noonan distinguishes Memorial and Remonstrance Against Religious Assessments from political efforts to manipulate religion for partisan advantage. Rather, Noonan sees the document as an effort by the Christian Madison to speak across denominational divides to fellow Christians and for Madison to raise points that those Christians would consider vital to their understanding of an otherwise deceptive issue. See id. at 85-87. This need for Christians to speak to one another across denominational divides represents yet another reason undermining the IRS position that religious consideration of social issues can be successfully confined within church walls.

237. Madison's Memorial and Remonstrance, written in opposition to the bill, garnered 1,552 signatures for itself and "met with the approbation of the Baptists, the Presbyterians, the Quakers, and the few Roman Catholics, universally; of the Methodists in part; and even of not a few of the Sect formerly established by law [Episcopalians]." NOONAN, supra note 231, at 74 (quoting Madison). In all, 10,929 petitioners indicated their opposition to the bill to the legislature, a number sufficient to indicate that "the electorate was up in arms," and guarantee that the plan was "“crushed." Id. (quoting Madison). 
during his 1788 Congressional campaign. ${ }^{238}$ Thus, from the Constitution's infancy, religion was permitted to speak in the state arena despite any wall separating the two.

The United States Supreme Court has declared that, at least since the framing of the Constitution, states in America have recognized that churches foster the "moral or mental improvement" of communities. ${ }^{239}$ The Court further noted that the states have sought to avoid taxation of churches to guard against the dangers associated with undermining the churches' fiscal insulation from the state. ${ }^{240}$ The Court noted that this experience has been both long and broad:

All of the 50 states provide for tax exemption of places of worship, most of them doing so by constitutional guarantees. For so long as federal income taxes have had any potential impact on churches-over 75 years-religious organizations have been expressly exempt from the tax....

It is obviously correct that no one acquires a vested or protected right in violation of the Constitution by long use, even when that span of time covers our entire national existence and indeed predates it. Yet an unbroken practice of according the exemption to churches, openly and by affirmative state action, not covertly or by state inaction, is not something to be lightly cast aside.

Consistent with Penn's and Williams's belief that faith communities should be an independent source of conscience for the state, "politicking from the pulpit was part and parcel of the electoral process" until the campaign intervention clause applied against Branch Ministries was passed in $1954 .^{242}$ In its action against the IRS, Branch Ministries demonstrated that in spite of the admonition in Walz v. Tax Commission of New York, religious freedom in this area was "lightly cast aside" 243 as the clause was passed "without benefit of congressional hearings, in the form of a floor amendment in the Senate." ${ }^{244}$ The amendment was ushered through Congress by Senator Lyndon Baines Johnson, future Senate majority leader and President of the United States, four months before his re-election in 1954. Johnson had realized the need for the clause when "nonprofit conservative groups joined conservative Texas Democrats in a challenge

238. Madison was at odds with Patrick Henry, the most dominant force in contemporary Virginia politics, and found that Henry had districted his home county with largely pro-Henry counties. A campaign advisor stressed that Madison would need to convince influential Baptist ministers to "exert" themselves for Madison to have a chance. The Baptists, in fact, held a pre-election meeting where "participants were reminded of Mr. Madison's 'many important Services' to the Baptists." Id. at 77. Madison went on to edge James Monroe in the election. See id. at 77-78.

239. Walz v. Tax Comm'n of N.Y., 397 U.S. 664, 672 (1970).

240. See id. at 673 .

241. Id. at 676, 678; see also James J. McGovern, The Exemption Provisions of Subchapter F, 29 TAX LAW. 523, 524 (1976) ("[The] history of mankind reflects that our early legislators were not setting precedent by exempting religious or charitable organizations.").

242. Pulpit Politics, supra note 10, at 8 B.

243. Walz, 397 U.S. at 678.

244. Memorandum in Support of Motion for Preliminary Injunction and Declaratory Relief at 28, Branch Ministries, Inc. v. Rossetti, 40 F. Supp. 2d 15 (D.D.C. 1999) (No. 1:95CV00724-PLF) (citing HOPKINS, THE LAW OF TAX-EXEMPT ORGANIZATIONS 327 (6th ed. 1992)). 
to his re-election to the Senate." ${ }^{245}$ As one might expect, given the notion and tradition of religious freedom in America, over the next forty-five years the IRS almost never applied the clause to religious organizations, ${ }^{246}$ and most of what we know of how the clause could apply to such organizations is based on its application in other nonprofit contexts.

If the principal governmental interest in this area is to permit religious organizations the opportunity to speak as an independent voice to power, then the IRS cannot use the principal state interest to justify its restrictions on issue sheets or voting records. ${ }^{248}$ Quite the opposite, the state should want religious organizations to participate freely and independently in the process of isolating, articulating, and prioritizing the questions of political life. The state should also especially welcome these expressions when they are most likely to stimulate public response, even if that should fall within a few days of an election. ${ }^{249}$ Thus, in these areas, both the right to free exercise of religion and the principal governmental interest test would lead to the conclusion that current IRS restrictions are unduly burdensome on religion. ${ }^{250}$

On the other hand, this governmental interest in respecting the exercise of independent religious conscience supports the spirit behind IRS restrictions on statements issued by religious organizations in two different contexts. First, the government has a legitimate interest in suppressing statements that seek to inflame a segment of the population without increasing understanding. Of course, this does not mean that the Church should not speak passionately on issues it cares about. Certainly the interest in promoting an independent conscience is furthered by education "that leads us to face, at the center of law and legal thought, the largest questions about human life and human purpose,",251 education capable of inspiring within many a profound or even zealous response. This is especially true in modern America where people are increasingly desensitized and disassociated, and where normal means of discourse seem unable to hold people's attention beyond the seven-second soundbites. To respond to this condition, increasingly powerful means of firing up public discourse are needed to jar people into engagement. ${ }^{252}$ One would have to con-

245. Pulpit Politics, supra note 10, at $8 \mathrm{~B}$ (citing James Davidson). More than 30 years after the clause's passage, Congress did articulate that the clause's purpose was to make the U.S. Treasury "neutral in political affairs." The significance of this, however, has been questioned. See Putney, supra note 156 , at 28 .

246. Branch Ministries v. Rossotti, 40 F. Supp. 2d 15, 22 (D.D.C. 1999) (plaintiffs maintained that the IRS had "never revoked the tax exempt status of a church qua church before" and could find only two examples of enforcement in any kind of religious context).

247. See supra text accompanying notes 81-92.

248. See supra text accompanying notes 89-92.

249. See supra text accompanying note 82 .

250. See supra text accompanying notes 105-171.

251. Conversations, supra note 218, at 15 (Joseph Vining commenting on H. JEFFERSON POWELL, THE MORAL TRADITION OF AMERICAN CONSTITUTIONALISM (1993)).

252. For the view that even the most profound efforts may have become futile, see ALDOUS HuXley, BRAVE NeW WORLD 210-15 (Perennial Classics ed. 1998) (noting where the efforts of "the 
cede, however, that this interest is undermined when a communicator seeks to inflame his audience by obfuscating rather than unveiling what is going on around them.

Similarly, this interest would not be furthered by statements indicating church support for a particular candidate or party without regard to its position on particular issues. "Politics," Aldous Huxley told us, "can be moral only on one condition: that its problems shall be spoken of and thought about exclusively in terms of concrete reality," in terms of real people and their lives rather than in terms of depersonified symbols and personified abstractions. ${ }^{253}$ When our political discussion fails in this regard, it can lead only to "idolatrous worship of the [s]tate, with consequent governmental oppression," and to violence. ${ }^{254}$

Under this view, the governmental interest would be to encourage the question "How then can we vote for Bill Clinton?," placed in the context of measuring political positions against sacred text, ${ }^{255}$ as well as President Clinton's appeal at New Psalmist for support of those candidates who back his specific programs. ${ }^{256}$ However, the governmental interest could be used to justify the regulation of statements made in a religious context like "The Democratic ticket. Say Amen!" 257 or "Stop the right wing extremists" were not connected to an effort to clarify and prioritize issues of concern.

The danger of a statement like "The Democratic ticket. Say Amen!" is that the process of deifying a candidate, regardless of what he stands for, undermines the likelihood religious organizations can function as consciences independent of state power. As Huxley realized, once we blindly determine that a particular party or candidate represents goodness, that party or candidate partakes "in the sacredness of the entity it represents, claims to give orders by divine right and demands the unquestioning obedience due to a god."259 The experiences noted earlier in the German Fatherland, the Greater Serbia, and even in America ${ }^{260}$ strongly caution against such practices.

Not only do such comments obscure the search for truth by falsely inflating their objects, they also undermine the credibility of their speakers. Thus, to the extent America has conservative Republican Christian churches, or to the extent it has African-American Democratic Christian churches, America does not have Christian churches that belong exclusively to Christ. And if America does

Savage" to communicate his liberating message are beyond the comprehension of his hollowed out and medicated audience).

253. Aldous Huxley, Words and Behavior, in COLLECTED EsSAYs 245, 255 (1964).

254. Id.

255. See supra text accompanying notes 26-28.

256. See supra text accompanying note 35 .

257. See supra text accompanying note 52 .

258. See supra text accompanying note 40 .

259. Huxley, supra note 253, at 253.

260. See supra text accompanying notes 177-205. 
not have Christian churches that belong to Christ, then it does not have Christian churches worth listening to. ${ }^{261}$

Huxley also warned of statements that suffer from "the error of speaking about certain categories of persons as though they were mere embodied abstractions. "262 Taken to its limits, this error results in believing that people who disagree with us cease to be individual human beings, but are merely members of a class, a class whose members have no personality other than being intrinsically evil. ${ }^{263}$ Once people become so classified, whether it be as gays or fundamentalists, abortion activists or anti-abortion advocates, they can become in the minds of their tragically misguided classifiers "mere vermin or, worse, demons whom it is right and proper to destroy as thoroughly and as painfully as possible. ${ }^{264}$

The reality of Huxley's observations is captured in Branimir Anzulovic's description of the process of preparing the Serbian people to participate in the ethnic cleansings of the 1990s. As Professor Anzulovic points out, "[a]ll genocidal campaigns, whether guided by nationalist or universalist myths, are based on lies that portray a particular community as superior to others but threatened by those others." 265 The victims of genocide must be seen as "demons" 266 who stand in the way of "the Utopian promise of a perfect society." becomes increasingly dangerous as twentieth century technology both facilitates mass communication and increases the means of destruction and violence. ${ }^{268}$

261. In 1933, while in Germany, Swiss theologian Karl Barth articulated six reasons that drew church members to entangle themselves in a "German Christian" movement that placed loyalty to the Nazi state above loyalty to God:

[S]ome fall victim in the honest belief that they have heard a messianic message, others on the strength of some very deep theological justification, which people are in the habit of finding with particular certainty just when they have allowed themselves to be most completely overtaken by "actuality," a third group on the simple-minded assumption that whatever is right in the political field is bound to be appropriate in the ecclesiastical field also, a fourth in the timid wisdom which is afraid of getting out of line or of getting its valuable power wasted, since this is the direction in which all is flowing, the fifth with the wise reservation that they only accept what is "good" in the movement, the sixth with the slightly underhand intention that they will join and then constitute the "necessary opposition" to overcome the "onesidedness" of the movement "from within."

BOSANQUET, supra note 131, at 125 . These reasons are instructive to people in any state where people of faith may be tempted to get lost in political loyalties.

262. Huxley, supra note 253, at 254.

263. See id.

264. Id.

265. ANZULOVIC, supra note 177 , at 7.

266. According to Professor Anzulovic:

In a perverse way, the ideology that generates a genocide demonstrates at the same time that most people committing it believe they are following their conscience. The self-defensive "kill so that you may not be killed" is usually not sufficient to mobilize the masses; the victim must be seen as a demon, and his killing as a universally beneficial act. Even at his worst, man likes to think that he is doing good.

Id. at 4 .

267. Id.

268. See id. at 7,8 
One can see on all sides of America's political spectrum efforts to deify and demonize. A conscience in political discourse must raise the debate above such efforts rather than descend into them. There is no governmental interest in encouraging such a descent. To those who argue that Americans are an enlightened people, who cannot be drawn in by such divisive and deceptive techniques, the conscience of faith in political discourse would still offer the advice, "and lead us not into temptation." 269

Although current IRS restrictions on statements that either specifically endorse candidates without association to specific issues, or that seek to deify or demonize people, groups, or parties may further a governmental interest in preserving religious organizations as a national conscience, that alone cannot justify the regulations. Any analysis of the constitutionality of an infringement also requires an examination of the degrees to which the action furthers the interest and unnecessarily infringes on the right. ${ }^{270}$ In the context of that examination, the Constitution might best trust religious organizations to act responsibly, thus leaving them to monitor themselves to avoid having these kinds of statements attributed to them, because the alternative, involving the IRS in day-today religious life, would threaten unnecessary infringements. ${ }^{271}$ Alternatively, the line might best be drawn to allow churches to engage in political activities so long as those activities did not become a substantial purpose of the church, a solution the Internal Revenue Code has reached in the lobbying context. ${ }^{272}$ Yet, even if identifying the real governmental interest here does not provide us with easy answers to all our questions, it does help us identify the real questions that we must strive to answer.

Having considered the positions of the IRS in the context of the government's interest in preserving religious organizations as an independent conscience, we now conclude by considering the rhetoric of the Chief Executive in the context of that interest. As President Clinton examines the religious and political landscape of America, he frequently recognizes its religious diversity, ${ }^{273}$

269. Luke 11:2-4 (the Lord's Prayer).

270. See, e.g., Planned Parenthood of Southeastern Pa. v. Casey, 505 U.S. 833 (1992) (requiring furtherance of a governmental interest to impose an undue burden on the exercise of a right); Moore v. East Cleveland, 431 U.S. 494 (1977) (requiring more than a marginal relationship between government action and legitimate interests); United States v. Carolene Products Co., 304 U.S. 144 (1938) (requiring rational relationship between governmental acts and individual interests).

271. See Walz v. Tax Comm'n of N.Y., 397 U.S. 664, 674 (1970).

272. See Putney, supra note 156, at 29,31-32. For an insightful and alternative discussion of where the lines need to be drawn in this area, see Anne Berrill Carroll, Religion, Politics and the IRS: Defining the Limits of Tax Law Controls on Political Expression by Churches, 76 MARQ. L. REV. 217, 259-61 (1992) (allowing, for example, churches, consistent with Federal Election Control Act standards, to participate in political campaign speech so long as it does not relate to "clearly identified candidates."); Ablin, supra note 57, at 581-87.

273. See, e.g., Religious Freedom Press Paper, President Clinton: Expanding Religious Freedom and Promoting Tolerance, Aug. 14, 1997, at 1, available in 1997 WL 890103 [hereinafter Promoting Tolerance]. 
its need for unity, ${ }^{274}$ and its obligation "to do the right things." 275 Beyond such sweeping phrases, however, the President struggles with the rest of the nation to rediscover the relationship in America between church and state.

President Clinton has described religious diversity as one of America's "greatest strengths over the last two hundred years." He has championed the resulting "tolerance of difference" as "one of the most profound achievements of the American Experiment." 276 While he has acknowledged the need to make room for religion in the public square, the President has emphasized that this space must be made "in a way that recognizes that most American of rights, the right to differ."277

Even as the President has applauded this diversity and tolerance, he also has acknowledged that America must transcend that diversity "so that we can find common ground and move forward together.",78 To demonstrate this need for unity, the President has stressed, "What works in a church? Working together, working for the future around shared values. What works in a family? What works at a business?" 779 The President has also noted that not all values Americans share are created equal. In this regard, President Clinton has indicated the need to share "good" values and move together "to do the right things." 280

One might wonder how to square the achievement of tolerance and the right to be different, with the need to share good values and find the right direction. Ultimately, President Clinton seems to recognize that the right to be different is not enough to bind a nation and that "[a]s our country becomes increasingly diverse, we must reaffirm our efforts to reach out to one another and to see past our differences to the values we hold in common." ${ }^{281}$ To facilitate this, the President has said that we need to "increase religious understanding and respect among our people," 282 we have to be humble enough as individuals to know

274. See, e.g., Clinton Speech, supra note 35, at 5 (President indicating he has "done everything [he] could to bring this country together, to reconcile the American people to one another so we could go forward together").

275. Prayer Breakfast, supra note 108, at 14.

276. Promoting Tolerance, supra note 273 , at 1.

277. Prayer Breakfast, supra note 108, at 3.

278. Promoting Tolerance, supra note 273, at 2.

279. Prayer Breakfast, supra note 108 , at 10.

280. Id. at 14.

281. Religious Freedom Day, supra note 106, at 1.

282. Id. Accord Herman Melville, Moby Dick 57-58 (Bantam Classic ed., 1981). The Presbyterian Ishmael seeks unity in faith with the good-hearted idolator Queequeg:

[W] hat is worship? - to do the will of God-that is worship. And what is the will of God? - to

do to my fellow man what I would have my fellow man do to me- that is the will of God.

Now Queequeg is my fellow man. And what do I wish that this Queequeg would do to me?

Why, unite with me in my particular Presbyterian form of worship. Consequently, I must then unite with him in his.

Id.; see also Ira C. Lupu, The Increasingly Anachronistic Case Against School Vouchers, 13 NotRE DAME J.L. ETHICS \& PUB. POL'Y 375, 375 (1999) ("My father was Jewish, and he had not led a religiously observant life, but his childhood experience had brought him close to Catholic clergy. In my presence (and, to my knowledge, throughout his stay), he welcomed the prayers of the priests he encountered at St. Peter's [Hospital]."). 
"nobody has all the answers," ${ }^{, 283}$ we must trust enough in the wisdom of "basic values to fall back on" them, ${ }^{284}$ and we must be open to the teachings, effectively the conscience, of "a church with a larger ministry.", 285

In the end, the President has recognized organized religion's role in America as that of an independent national conscience. He has stressed the importance of listening to those values:

It is no accident of authorship that the right to free exercise of religion is the first freedom granted by our Bill of Rights. The framers of the Constitution well recognized the awesome power of religious liberty, not only to unite the citizenry in common cause, but also to empower us to question age-old beliefs and lift this nation toward enlightenment. Today, as we face a crisis of conscience in our families and communities, as children murder children in our schools, as neighbor turns away from neighbor on frightening city streets-today, more than ever, we see the fundamental wisdom of our country's forefathers. For at the heart of this most precious right is a challenge to use the spiritual freedom we have been afforded to examine the values, the soul, and the true essence of human nature.

Religious freedom helps to give America's people a character independent of their government, fostering the formation of individual codes of ethics, without which a democracy cannot survive. ${ }^{286}$

The essence of the President's message appears to be that diversity is no more an alternative to truth in politics than partisan advocacy is an alternative to truth in litigation. ${ }^{287}$ Rather diversity, like partisan advocacy, must serve as a vehicle for truth, or justice will erode. It is not enough that in the context of religion we respect a right to be different if we merely couple that with a corresponding right not to encounter different views or to ignore them. Instead, we must couple that right with a corresponding responsibility. ${ }^{288}$ We must embrace a responsibility to increase religious understanding and respect. We must embrace a responsibility to listen to one another.

If religious diversity is to be a vehicle of truth, then we must not treat it like a trip to the zoo, where we are pleased to be able to view all the different animals but grateful we do not have to take any of them home. Instead, we must

283. Prayer Breakfast, supra note 108, at 10; see also id. ("[T]he only people Jesus was really hard on ... were the Pharisees and Saducees and the religious hypocrites who appeared to have all the revealed truth"); Clinton Speech, supra note 35, at 4 ("Now we see through a glass darkly, but then face to face." (quoting 1 Corinthians 12:12)); Thomas C. Berg, Church-State Relations and the Social Ethics of Reinhold Niebuhr, 73 N.C.L. REV. 1567, 1567 (1995) ("What is too often missing from the [culture wars] debate is any sense of humility, any awareness that one's own perspective may be partial, and any acknowledgment that although moral views (left or right) must relate to politics, social life is usually too complex to allow for simple solutions."); accord Rich Mullins, on HOMELESS MAN: THE RESTLESS HEART OF RICH MULLINS (Word Entertainment 1998) ("[I]f we were given the Scriptures, it was not so that we could prove that we were right about everything; if we were given the Scriptures, it was to humble us into realizing that God is right, and the rest of us are just guessing.").

284. Prayer Breakfast, supra note 108, at 10.

285. Id. The need for religious voices in America to speak truth to power and the need for America to address moral issues with both wisdom and humility is a theme of MORAL TRADITION, supra note 15. See Lee, supra note 128, at 1206; Conversations, supra note 218, at 32-33 (Randy Lee speaking).

286. Proclamation No. 6646, 59 Fed. Reg. 2925 (1994) (Religious Freedom Day, 1994).

287. MODEL RULES OF PROFESSIONAL CONDUCT preamble.

288. See MARY ANn GLEndon, Rights TAlk 76-108 (1991) (discussing responsibilities as an essential part of the democratic equation). 
treat it as a shopping trip to the mall, a trip in which we intend to purchase the goods we need to furnish our home.

To find the good values that the President says the nation needs to accomplish the right things, America must, as the First Lady has said, address its "sleeping sickness of the soul." 289 Recognizing that all religious organizations, made up as they are of people, have their moments in which they are prideful, stiff-necked, distracted, impatient, covetous, or despondent, no one such organization can guarantee that it can unfailingly provide the necessary wake-up call. Rather, America, like King Jehoshaphat of Judah, must listen to the voices of all its prophets, ${ }^{290}$ trusting, as John Howard Yoder might say, in the "power of truth" to assert itself in the marketplace of ideas. ${ }^{291}$

To do otherwise, to champion diversity with no intention to listen to diverse voices, dooms America to a society as confused as that surrounding the ancient Tower of Babel. For all the glorious aspirations that tower's builders had, they ultimately had to abandon the project when they ceased to be able to communicate with one another and, thus, to be able to work together toward a common goal. $^{292}$ Those familiar with discourse in America already see parallels to the Babel experience present in modern America. Both Jefferson Powell and Alysdair MacIntyre, for example, see in America the inability to communicate about things that matter and the resulting paralysis in the ability to join together for good:

The most striking feature of contemporary moral utterance is that so much of it is used to express disagreements, and the most striking feature of the debates in which these disagreements are expressed is their interminable character. I do not mean by this just that such debates go on and on and on-although they do-but also that they apparently can find no terminus. There seems to be no rational way of securing moral agreement in our society. ${ }^{293}$

If one could criticize the President's efforts in his attempt to find unity in the midst of diversity, it would be that he needs to be more ambitious in engaging at a deeper level the dialogue with this independent, religious conscience. President Clinton, for example, has praised Secretary of Education Richard Riley's "moral code," designed to fill the void created by the limits on religion in public schools. ${ }^{294}$ This moral code, as the President perceives it, calls for people to be "honest and trustworthy, reliable, to have respect for themselves, for others, for property, and for our natural environment, to be good citizens, and . . . to treat one another with civility and tolerance and to exercise personal responsibil-

289. Supra text accompanying note 147.

290. See 2 Chronicles 18:6.

291. SHAFFER, supra note 18, at 23 (quoting John Howard Yoder) ("Jesus rejected the power of the sword, of the lie, of social stratification ... but he exercised other kinds of power effectively: the power of truth, of love, of community.").

292. See Genesis 11:1-9.

293. Powell, Moral Tradition, supra note 15, at 38 (quoting Alysdair Macintyre, After VIRTUE 6 (2d ed. 1984)).

294. Prayer Breakfast, supra note 108, at 2. 
ity." ${ }^{295}$ As so described, the code is a call to be a good and pleasant American, and that is, no doubt, a good place for America to begin moral discourse. But moral discourse must go deeper. America in its Gilded Age ${ }^{296}$ and Germany under National Socialism ${ }^{297}$ articulated their national moral goals in a similar way and ultimately harvested tragic fruits. ${ }^{298}$

An illustration of how America can advance moral discourse in conjunction with an independent religious conscience is gained by contrasting two meetings held in 1999, one between Pope John Paul II and Secretary of State Madeline Albright and the second between the Pope and President Clinton. ${ }^{299}$ In the former meeting, Secretary Albright symbolically stepped across cultural and ideological divides to speak to the Pope in his own language, Polish, and the Pope in turn showed a willingness to cross those divides himself by speaking to her in English. ${ }^{300}$ While the Secretary obviously did not yield to the Pope on all points, the two sought to discuss specific issues and differences, and they did so in a way that reflected the Secretary's recognition of the Pope's past successes, her respect for his ongoing efforts, and her desire to keep open the lines of communication. ${ }^{301}$ During the meeting, the two discussed the U.S. embargo of Cuba, U.N. sanctions against Iraq, the fighting in Kosovo, and the promotion of religious freedom in China. ${ }^{302}$ The Secretary told the Pope that she believed "he had been instrumental in the fall of communism in his homeland of Poland" and she would be watching carefully how his efforts in Cuba developed. ${ }^{303}$ Afterwards Secretary Albright described the meeting as "fabulous," and the Vatican

295. Id.

296. Eerdman claims that during the Gilded age:

American civilization, while never "Christian" in a strict sense, was held together in part by a shared set of values that had a large Protestant component. Children were taught from an early age to play by the rules, and virtually everyone knew of the Ten Commandments, the value of work, and the idea that virtue should be rewarded. During the Gilded Age, these principles were still taught not only in the homes but also in the public schools.

EERDMAN, supra note 21, at 281

297. The Nazis encouraged the German people to "return to the heroic Jesus' whom one may discover if one selects from the gospels 'all that speaks to our German heart' and which 'and of this we may be proud, is entirely consistent with the demands of National Socialism!"” BoSANQUET, supra note 131 , at 132 .

298. See supra text accompanying notes 181-183, 196-200; see also Anthony J. Fejfar, In Search of Reality: A Critical Realist Critique of John Rawls' A Theory of Justice, 9 ST. LOUIS U. PUB. L. REV. 227, 289-94 (1990).

299. These meetings would be better characterized within section 501(c)(3) as "attempting to influence legislation," something that the section will not allow religious organizations to do as a "substantial part of [their] activities," rather than as "participating in a political campaign." The lessons they provide, the most effective way for faith and power to interact, transcend the contextual difference.

300. See Haller, supra note 185 , at A26.

301. See id. Secretary Albright may be particularly well disposed to deal with assimilating religious diversity. She has a Jewish heritage, was raised Roman Catholic, and later joined the Episcopal Church. See id. Secretary Albright also had Czech relatives die in the Holocaust. See id.

302. See id.

303. Id. In addition, the Secretary "expressed her tremendous admiration for the Pope's moral and spiritual leadership, for his achievements on behalf of freedom and for his expressions of solidarity with people of every faith who suffer because of oppression, poverty and war." Id. 
indicated that it had facilitated "'a useful exchange of opinions on the responsibility of the United States in the world arena.",

The President's meeting with Pope John Paul II on January 26, 1999 appeared to be markedly different from the Pope's meeting with the Secretary of State. While the nature of the private policy meeting between the two leaders has remained private, ${ }^{305}$ the public discussions surrounding it reflect a lack of communication. The Pope used his public speech with the President that day to remind the President and America of the Pope's "profound policy differences" with the President. ${ }^{306}$ The Pope addressed important, divisive issues such as abortion, euthanasia, and racial equality, specifically and directly. ${ }^{307}$ The President, meanwhile, chose to ignore the specifics and the policy differences expressed in the Pope's message, ${ }^{308}$ though the President did acknowledge the Pope for never letting America "forget our responsibilities"309 and praised him for his role in the "revolution of values and spirit' that helped end the Cold War."310

While the Pope sought to act as an independent conscience, the President raised the moral code of the good American. Thus, when the Pope pointed out a conflict "between a culture that affirms, cherishes, and celebrates the gift of life, and a culture that seeks to declare entire groups of human beings-the unborn, the terminally ill, the handicapped, and others considered unuseful-to be outside the boundaries of legal protection," and called for "a higher moral vision [to] motivate the choice for life,"311 the President assured that America would work harder to be "an example of justice and civic virtues, freedom fulfilled and goodness at home and abroad,",312 and offered himself as an "apostle of hope." 313

Where the Pope and the Secretary sought to transcend language barriers by speaking to each other in the other's language, the Pope and President could not seem to speak on the same topic in the language they shared. While both the Secretary and the President praised the Pope and his accomplishments, only the Secretary seemed engaged by his ideas and perspectives. While neither the Secretary nor the President acceded to the Pope's wishes, the Pope left the Secretary with a sense that there was reason to speak again. All in all, the Albright meeting is a better example of the kind of religious dialogue that the government has an interest in pursuing.

304. Id. (quoting the Vatican).

305. See Bob Deans, Pope Calls for "Higher Moral Vision," DAYTON DAILY NEWS, Jan. 27, 1999, at $4 \mathrm{~A}$.

306. James Bennet, Again Clinton Creates His Own Political Aura, N.Y. Times, Jan. 27, 1999, at A16.

307. See Deans, supra note 305 , at 4 A.

308. See id.

309. Bennet, supra note 306, at A16.

310. Deans, supra note 305, at 4A.

311. Id.

312. Bennet, supra note 306, at A16.

313. Maureen Dowd, The Apostle of Hype, N.Y. TimES, Jan. 27, 1999, at A25. 
The January meeting between the President and the Pope is not atypical of Administration-Vatican relations, ${ }^{314}$ in which both sides agree that " "progress to date has been very hard fought and very small,",315 nor even AdministrationChurch relations more generally. ${ }^{316}$ As recently as the conflict in Kosovo, appeals by the Pope for diplomatic efforts or cease fires were locked outside the political imagination of an Administration focused only on the debate of what level of violence should be used. ${ }^{317}$ One might have expected the President to seek greater engagement with the ideas of a world leader whom the President had acknowledged as a principal player in the demise of communism in Eastern Europe. Perhaps the Pope sensed that the military bombardment could not be a final chapter to the conflict. It would only keep the claims for revenge and the cycle of terrorism and official aggression that had marked the region simmering. ${ }^{318}$ Even now this area boils over in open mockery of the claims of peace. ${ }^{319}$

In the President's defense, the Pope's advice may not have made much sense at the time it was given. Still, there is a lesson in that. A good conscience often makes the least sense when it is most needed. The conscience does not call us to be pragmatic but to be good, and it is often only later that we understand that our faith in the power of goodness was warranted.

In all of this, the President is like all people of faith who acknowledge having a conscience but struggle with how to respond to it. ${ }^{320}$ The problem is even more complex for a President called to listen to the multitude of moral voices

314. See supra text accompanying notes 302, 307 (listing several problem areas); but see Cheryl Strauss Einhorn, No Big Deal: Open Cuba Wouldn't Be a Boon for U.S. Farms, BARRon's, Feb. 1, 1999, at MW14 (acknowledging progress in differences over policies toward Cuba).

315. Deans, supra note 305, at 4A (quoting P.J. Crowley).

316. See, e.g., Gayle White, Southern Baptist Convention Baptists Eye TV Superstation; Re-elected President of SBC Urges Church to Spread Gospel Through its Own TV Ministry, ATLANTA J. \& ATLANTA CONST., June 16, 1999, at 3A (acknowledging differences between the President's policies and the teachings of his Baptist Church).

317. Patrick Marrin, Nonviolence is Possible, and No Longer Just an Option, NAT. CATH. REP., Apr. 30, 1999, at 6.

318. See id.

319. David Hackworth has notes that the NATO victory in Kosovo has not stopped the tragedy in the Balkans. He observes that:

[S]ince V-K Day-'Victory in Kosovo'-more Serb civilians have been slaughtered than ethnic Albanians were before the NATO air campaign began. Since NATO's last bomb fell, scores of Serbians, Gypsies and Jews have been murdered, more than 200 Serb villages have been torched and 50 Christian churches have been defiled or destroyed. . . NATO troops flat haven't been able to stop the violence or the ethnic cleansing.

David H. Hackworth, Tables Turn, Bullets Fly, Sun-SENTINEL Aug. 25, 1999, at 19A.

320. As Rich Mullins put it, we spend the better part of our lives telling God we love Him and be-

lieve in Him, but we just have to do this one thing our way. At some point, though, after you've gone through that long enough, after you've beat your head up against that wall for a good decade, you come out of it, and you have accomplished all of the damage that God wanted to save you from, and all you can do at that point is go "Wow. I am so sorry that when You told me to walk in faith, I refused to do it, and now I know why You gave the commands that you gave. Now I know why You said what You said. And I wish that I didn't have to know that, in order to obey it."

Introduction to "Growing Young," in Twenty THE COUNTDOWn MAGAZINE ReMEMBERS Rich Mullins (Twenty the Countdown Magazine 1997). 
included in a religiously diverse nation. Still, we all must listen to and evaluate the messages those voices offer, even when we do not necessarily embrace the religious tradition of their speaker.

As noted before, the voices themselves can make the task easier and more productive by preserving their independence. An old episode of "Father Knows Best" illustrates the point. In the episode, Bud Anderson, the town's high school baseball hero, was being kept out of the big game by his mother so he could study for his church confirmation exam the next day, something Bud, a slow learner anyway, had neglected to do up to that point. Bud needed to pass the exam to gain full adult membership in the church.

As the day of the game wore on, it became increasingly clear that the team could not win without Bud. Finally with two outs and the bases loaded in the bottom of the final inning, his team down by four runs, Bud was whisked to the game for one at bat. Bud drove a hit deep into the outfield, his three teammates scored in front of him, and Bud rounded third. The outfielder threw the ball to the plate; Bud slid; and the umpire called him out.

Bud's team and fans stormed the field. "Bud," they argued, "was safe. How could anyone not see that?" As the crowd threatened to grow ugly, Bud himself stepped forward and said, "I was out. He tagged me before I touched the plate."

It is a tough truth for someone in Bud's position to recognize. Certainly his loyalty to his team or his own ambition could have blinded him to it. But somehow for Bud the truth was bigger than the team, bigger even than Bud himself.

The next day before the whole congregation, Bud floundered in his examination. He was not good at the layers of doctrine and dogma. Yet, as Bud stood before the congregation humbled, still feeling the disappointment of the day before, his pastor put his arm around Bud and welcomed him into the Church. The pastor told the congregation how the day before Bud had had the courage to face and speak the truth, when that truth had been unpopular and when it had been painful. This is, the pastor said, what we need in the Church. And that is, the Nation cried, what we need from the Church.

\section{$\mathrm{V}$ \\ CONCLUSION}

Section 501(c)(3) as applied to Branch Ministries by the IRS, pays churches through tax-exempt status to be silent on issues deemed by the state to be political. Such an application stands in stark contrast not only to the constitutional guarantee that the federal government will not seek to abridge the free exercise of religion, ${ }^{321}$ but also to the image of the President, himself, taking the pulpit at New Psalmist Baptist Church to encourage the support of the faithful for his party's candidates. This paradox demands resolution.

321. U.S. Const. amend. I ("Congress shall make no law ... prohibiting the free exercise [of religion]"). 
As this article has shown, the resolution of this tension in executive branch behavior requires an understanding of both religion and government. When one speaks of the free exercise of religion, one speaks not, as the IRS would maintain, of a dynamic that can be neatly confined within the brick walls of a Sunday service. ${ }^{322}$ Rather, one speaks of a dynamic that insists on touching hearts in all reaches of the community at all times. Religious discourse necessarily encompasses political issues, but also embraces the most important questions of our lives, why we are here and where we are going. ${ }^{323}$ Religion insists that it alone identify what questions are important and in what order those questions are to be addressed. Religion is not merely a source of joy or consolation. Rather, religion seeks to be a source of direction and purpose even as it remains mysterious and humbling to the human mind. Given this understanding of religion, one cannot say that religion is not burdened by being excluded from politics, as the IRS has insisted. In the end, that "which activates our decision-making process and gives us a frame of reference for conduct, behavior and lifestyle" must be transcendent, even into politics. ${ }^{324}$

To understand government is to understand that it "is more than the naked struggle of power against power." 325 Rather, it "is what we do as an alternative to tyranny, and we try to do it well, and we try to do it ethically."326 Government is designed to do good and to do right things for the community that gives it life. But to do so requires government to find an independent moral compass. In a "contemporary postmodern World" that considers the search for truth "a quaint anachronism," government must yearn to be true to its citizens, ${ }^{327}$ and, thus, it must find an uncompromising source of truth.

Once this understanding of religion and government is accepted, it is clear that government's interest in this realm is not to find a way to wall religion out of government but to find a way for religion to contribute to the community's effort to seek truth ${ }^{328}$ and do good. The interest is in finding a way to keep religion close enough to be heard as a conscience but separate enough that religion will not forget what it is and what it needs to say.

One might argue that such a view rests on too optimistic an understanding of religion, ${ }^{329}$ but as this article has shown, the view rests not on an ignorance of

322. For an insightful discussion of the effort to confine religion to private life and "to police" the resulting boundary between religion and politics, see Frederick Mark Gedicks, Public Life and Hostility to Religion, 78 VA. L. REV. 671, 678-79 (1992).

323. See, e.g., Joseph Allegretti, Lawyers, Clients, and Covenant: A Religious Perspective on Legal Practice and Ethics, 66 FORDHAM L. REV. 1101, 1104 (1998).

324. Cantwell, supra note 124, at 1156.

325. H. Jefferson Powell, Introduction of Walter E. Dellinger III at The Constitution under Clinton: A Critical Assessment (Sept. 23, 1999).

326. Walter E. Dellinger III, Keynote Speech at The Constitution under Clinton: A Critical Assessment (Sept. 23, 1999).

327. William P. Marshall, In Defense of the Search for Truth as a First Amendment Justification, 30 GA. L. REV. 1, 2 (1995).

328. See William P. Marshall, Truth and the Religion Clauses, 43 DePAUl L. REV. 243, 266-67 (1994).

329. See, e.g., Hamilton, supra note 233 , at $361 \&$ n.12. 
religion's darker side but sustains itself in spite of religion's darker side. ${ }^{330}$ Even a casual glance through history reveals that people do bad things in the name of religion and that some religions instruct people to do bad things. As noted earlier, racial oppression, religious persecution, war, greed, and indifference have all had their moments in America under the banner of religion. ${ }^{331}$ But religion led Roger Williams to stand up for the property rights of Native Americans, wrenched America out of the grips of slavery, guided Dorothy Day's defense of oppressed workers, and sustained Martin Luther King's defense of an oppressed people. Religion has been the light in many of America's darkest moments. Defining the integration of religion and politics is no doubt messy and challenging, but given the values at stake, we have no choice but to pursue that integration.

In C.S. Lewis's book The Silver Chair ${ }^{333}$ a young girl who is swept off to an enchanted place seeks out a stream and kneels to drink. As she prepares to drink, she encounters a great lion. He tells her to drink. "But will you eat me?" the girl asks. "I have swallowed up whole cities," the lion answers. "Then I will find another stream," the girl protests. To which the lion responds, "There is no other stream."

Faith is like that. It is a powerful force, the fire encountered by Moses that burned, but did not consume the bush. ${ }^{334}$ I may wish to flee those flames, to quench my thirst elsewhere, but then I must ask, "Where else can I go; there is no other stream?",335

The same may be said on behalf of America as well, its history marred like that of many other nations with dark moments when its religious voices have failed it, and yet that same history highlighted by glorious moments when its religions have made America do good. As we search today for that independent conscience that can stand apart from government but still speak about the government, we may hesitate to seek it among the fountain of diverse religious voices we have. But, in the end, America is left to ask itself, "Where else can I go, for there is no other stream."

330. See generally William P. Marshall, The Other Side of Religion, 44 HASTINGS L.J. 843 (1993).

331. See supra text accompanying notes 193-205.

332. See Kent Greenawalt, Judicial Resolution of Issues about Religious Conviction, 81 MARQ. L. REV. 461, 472 (1998); see, e.g., Samuel J. Levine, Rethinking the Supreme Court's Hands-Off Approach to Questions of Religious Practice and Belief, 25 FORDHAM URB. L.J. 85 (1997).

333. C.S. LEWIS, THE SILVER CHAIR 22-23 (Scholastic ed. 1995) (paraphrase).

334. Exodus 3:2.

335. See John 6:67-68 ("Jesus then said to the Twelve, 'Do you also want to leave?' Simon Peter answered him, 'Master, to whom shall we go? You have the words of eternal life.'”). 


\section{CHRISTIAN BEWARE}

\section{Do not put the economy ahead of the Ten Commandinents.}

\section{Did you know that Governor Bill Clinton...}

- Supports abortion on demand? (Violates Exo. 20:13, Lev. 20:1-5)

- Supports the homosexual lifestyle, and wants homosexuals to have special rights? (Violates Exo. 20:14, Lev. 20:13. See also Rom. 1:26,27)

- Promotes giving condoms to teenagers in public schools? (Violates Exo. 20:12, Col. 3:5. See also Rom. 1:28-32) Bill Clinton is promoting policies that are in rebellion to God's Laws. In our desire for change, do we really want as a president and a role model for our children a man of this character who supports this type of behavior?

\section{But what about the economy?}

Yes, we are in tough economic times, but God forbid that we sell out our most sacred beliefs in a vain hope of financial gain. How can we expect God to bless our economy if we plunge down a path of immorality? (Deut. 28)

The Bible warns us to not follow another man in his sin, nor help him promote sin-lest God chasten us.

(See Deut. 13, Jer. 23, Prov. 4:14; 11:21; 16:5, 1 Tim. 5:22)

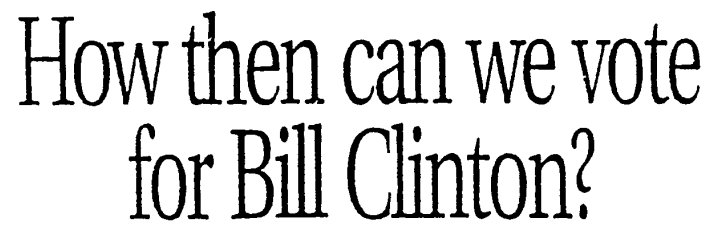

